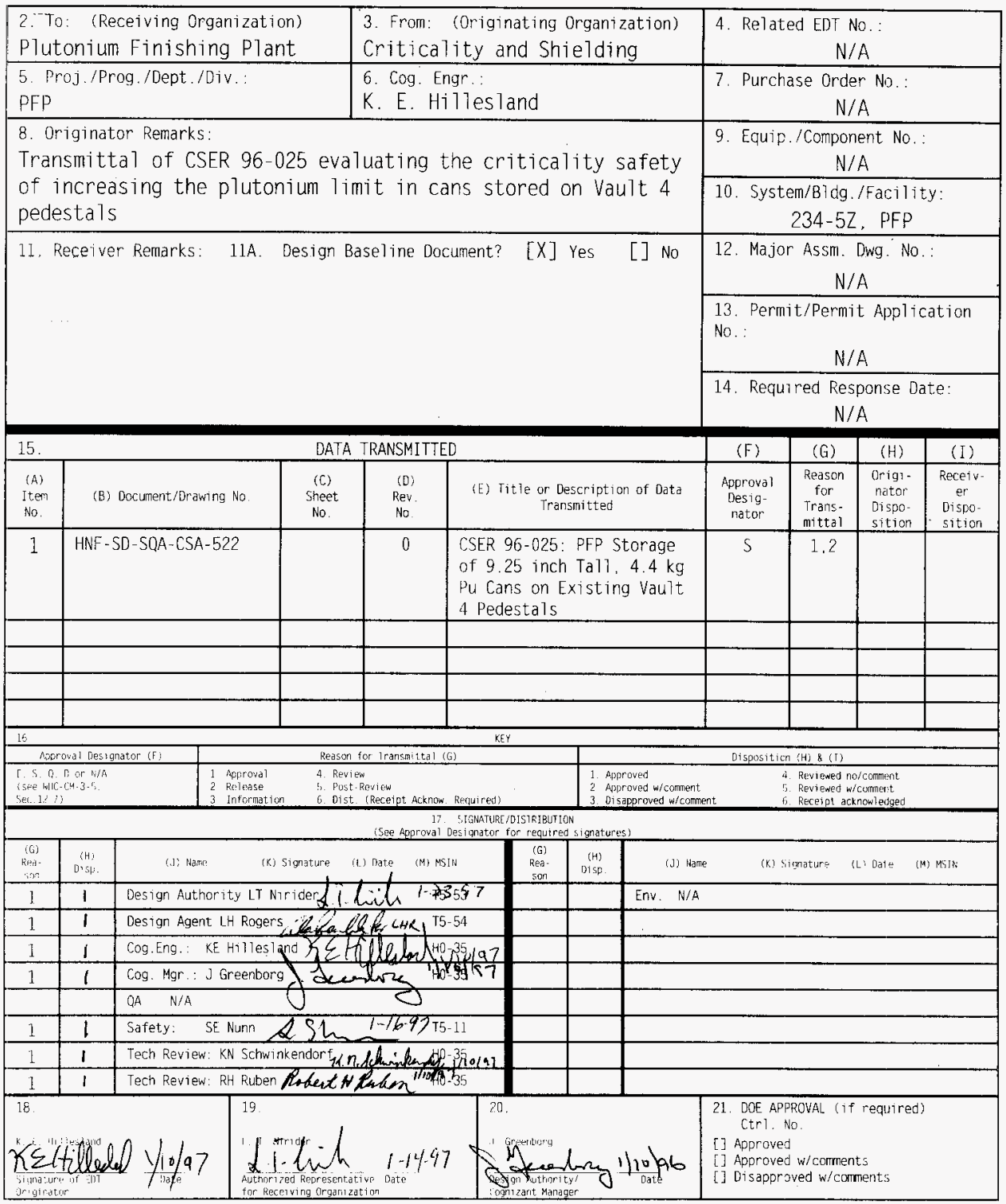




\title{
CSER 96-025: PFP Storage of 9.25 inch Tall, 4.4 kg Pu Cans on Existing Vault 4 Pedestals
}

\author{
Karl E. Hillesland \\ Fluor Daniel Northwest, Inc., Richland, WA 99352 \\ U.S. Department of Energy Contract DE-AC06-96RL13200
}

EDT/ECN: 620285

Org Code: 403

B\&R Code: EW7003000
UC: 507

Charge Code: E55780

Total Pages: 4442

Key Words: Criticality, Vault, Plutonium

Abstract: A nuclear criticality safety analysis has been performed to increase the approved plutonium mass limit for cans stored in Vault \#4 cubicles at PFP. The cubicles were approved to hold up to $2.5 \mathrm{~kg}$ of plutonium on each pedestal. The purpose of this CSER is to accommodate the storage of $4.4 \mathrm{~kg}$ of plutonium in $\mathrm{PuO}_{2}\left(5.0 \mathrm{~kg} \mathrm{PuO}_{2}\right)$ in Vault \#4 cubicles. The highest $\mathrm{k}_{\mathrm{eff}}$ calculated for all possible scenarios is $0.868 \pm 0.003$ when every other cubicle is left vacant, which is well below the criticality safety limit of $k_{\text {eff }}=0.935$. Consequently, an increase of plutonium mass to $4.4 \mathrm{~kg}$ per can is within acceptable safety limits for this configuration.

TRADEMARK DISCLAIMER. Reference herein to any specific commercial product, process, or service by trade name, trademark, manufacturer, or otherwise, does not necessarily constitute or imply its endorsement, recommendation, or favoring by the United States Government or any agency thereof or its contractors or subcontractors.

Printed in the United States of America. To obtain copies of this document, contact: WHC/BCS Document Control Services, P.O. Box 1970. Mailstop H6-08, Richland WA 99352. Phone (509) 372-2420; Fax (509) 376-4989.

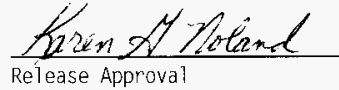

Rélease Approva?
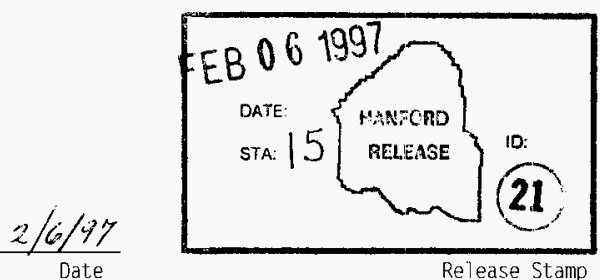

Release Stamp

\section{Approved for Public Release}




\section{CONTENTS}

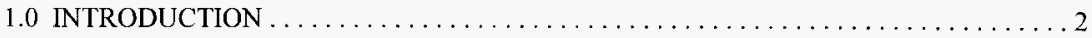

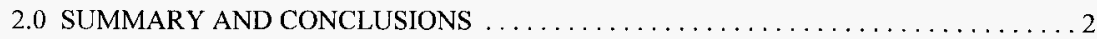

4.0 DESCRIPTION OF SYSTEM AND FACILITY $\ldots \ldots \ldots \ldots \ldots \ldots \ldots \ldots \ldots \ldots \ldots$

5.0 METHODOLOGY $\ldots \ldots \ldots \ldots \ldots \ldots \ldots \ldots \ldots \ldots \ldots \ldots \ldots \ldots \ldots$

6.0 EVALUATION AND RESULTS $\ldots \ldots \ldots \ldots \ldots \ldots \ldots \ldots \ldots \ldots \ldots \ldots \ldots$

6.1 MODEL DESCRIPTION AND ASSUMPTIONS $\ldots \ldots \ldots \ldots \ldots \ldots \ldots \ldots$

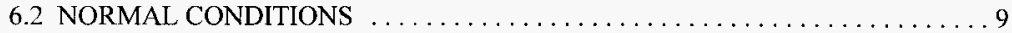

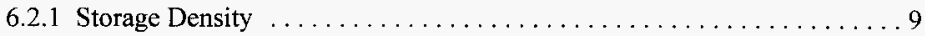

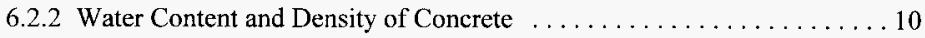

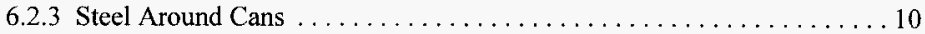

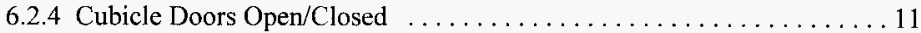

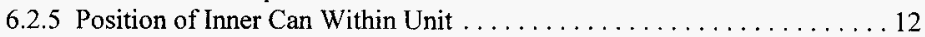

6.2.6 Person Moving a Can Within Cubicle Interior $\ldots \ldots \ldots \ldots \ldots \ldots \ldots 14$

6.2 .7 Storage of Fissile Material Near Vault $\# 4 \ldots \ldots \ldots \ldots \ldots \ldots \ldots \ldots$

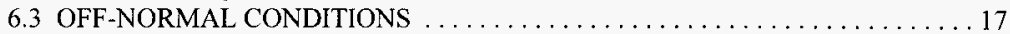

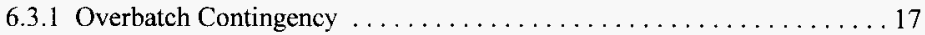

6.3 .2 Loaded Fixed Array Wagon Contingency . . . . . . . . . . . 18

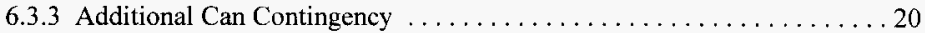

6.3 .4 Internal Moderation Contingency $\ldots \ldots \ldots \ldots \ldots \ldots \ldots \ldots \ldots \ldots \ldots$

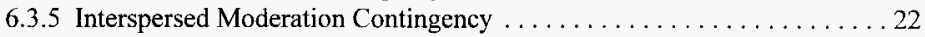

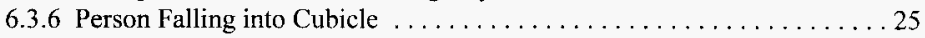

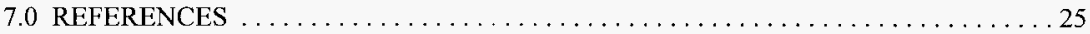

APPENDIX A: INDEPENDENT REVIEW COMMENTS AND CHECKLIST $\ldots \ldots \ldots \ldots$ A-1

APPENDIX B: MONK VALIDATION $\ldots \ldots \ldots \ldots \ldots \ldots \ldots \ldots \ldots \ldots \ldots \ldots \ldots$

APPENDIX C: MONK INPUT FILES $\ldots \ldots \ldots \ldots \ldots \ldots \ldots \ldots \ldots \ldots \ldots \ldots \ldots \ldots \ldots \ldots$ 


\section{CSER-96-025}

Title: CSER 96-025: PFP Storage of 9.25 inch Tall, $4.4 \mathrm{~kg}$ Pu Cans on Existing Vault 4 Pedestals

Prepared by: $\$ \sum$ fillesten)

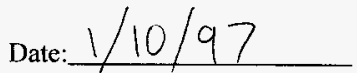

K. E. Hillesland, Engineer

Criticality and Shielding

Reviewed by:

K. N. Schwinkendorf, Engineer

Date: $1 / 10 / 97$

Criticality and Shielding

Reviewed by: Rakect 4 then

Date: $1 / 10 / 97$

R. H. Ruben, Scientist

Criticality and Shielding

Approved by:

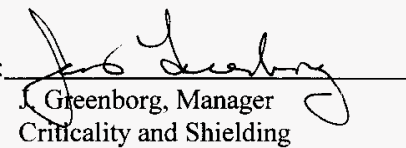

Date: $1 / 10 / 97$

\subsection{INTRODUCTION}

A nuclear criticality safety analysis has been performed to increase the approved plutonium mass limit for cans stored in Vault \#4 cubicles at PFP. The cubicles were approved to hold up to $2.5 \mathrm{~kg}$ of plutonium in plutonium oxide $\left(\mathrm{PuO}_{2}\right)$ on each pedestal $(\mathrm{Chiao}, 1978)$. The purpose of this CSER is to accommodate the storage of $4.4 \mathrm{~kg}$ of plutonium in $\mathrm{PuO}_{2}(5.0 \mathrm{~kg}$ $\mathrm{PuO}_{2}$ ) in Vault \#4 cubicles. The plutonium will be placed into a package called the Hanford Convenience Can (HCC). The HCC allows direct transfer to the DOE 3013 standard outer packages without material rehandling.

The cubicles will be used to hold cans of dry $\mathrm{PuO}_{2}(\mathrm{H} / \mathrm{Pu}<2)$. The $\mathrm{PuO}_{2}$ is quadruple canned in the HCC configuration, with each can being sealed or welded shut. Each of the cans are made of metal, and have lids on them. There may also be one or more plastic bags around the cans. 


\subsection{SUMMARY AND CONCLUSIONS}

This analysis has shown that the storage of $4.4 \mathrm{~kg}$ plutonium in the Hanford Convenience Can (HCC) under the controls listed in section 3 is safe from a criticality stand point. No single identified contingency exceeds the criticality safety limit of $\mathrm{k}_{\mathrm{eff}}=0.935$ for plutonium systems calculated using the MONK6B code.

All results of this analysis can be found in Section 6 . The worst case normal condition scenario was found to be the case of closing all the doors in the vault (case cskip). For this case, $\mathrm{k}_{\mathrm{eff}} \pm 1 \sigma$ was calculated to be $0.858 \pm 0.003$.

For the off normal condition (contingency) analysis the overbatch case with the doprs closed (cdbatch) is calculated to be $k_{\text {eff }} \pm 1 \sigma$ of $0.862 \pm 0.003$. When a fully loaded Fixed Array Wagon is brought into the room, thus violating the limit that there be only one can in transit at a time, the $k_{\text {eff }} \pm 1 \sigma$ becomes $0.851 \pm 0.003$. When an extra can is placed on the floor of the vault and the doors are closed, the $\mathrm{k}_{\mathrm{eff}} \pm 1 \sigma$ becomes $0.859 \pm 0.003$, which indicates a negligible change in reactivity. If the doors are open, and a person is moving two cans around inside the cubicle, again violating the limit of one can in transit at a time, the $k_{\text {eff }} \pm 1 \sigma$ becomes $0.850 \pm 0.003$. The internal moderation contingency case (case cint4) has a maximum $\mathrm{k}_{\mathrm{eff}} \pm 1 \sigma$ of $0.868 \pm 0.003$. For optimal interspersed moderation (case cp0002), the $\mathrm{k}_{\mathrm{eff}} \pm 1 \sigma$ is $0.859 \pm 0.003$. The $\mathrm{k}_{\mathrm{eff}} \pm 1 \sigma$ for a case where a person falls into the cubicle (case opincell) is $0.806 \pm 0.003$.

As can be seen, all of the normal and off-normal results are below the criticality safety limit. This analysis shows that the mass loadings of the cans may be increased from the current $2.5 \mathrm{~kg}$ of plutonium limit to $4.5 \mathrm{~kg}$ of plutonium provided that all limits and requirements listed in section 3 are followed. Since no single identified contingency exceeds the criticality safety limit, this CSER meets the requirements for criticality analysis of the Hanford Site Nuclear Criticality Safety Manual, CM-4-29. 


\subsection{DESIGN FEATURES AND ADMINISTRATIVELY CONTROLLED LIMITS AND REQUIREMENTS}

are:

The administratively controlled limits applicable to this evaluation of the vault \#4 pedestals

1) Cubicles shall be used for storage of HCC containing up to $4.5 \mathrm{~kg}$ of plutonium in oxide form only, and every can must be placed on an available pedestal.

2) For a cubicle containing plutonium, the other cubicles sharing a wall with the given cubicle shall be left vacant.

3) The $\mathrm{PuO}_{2}$ shall be moderation controlled to an $\mathrm{H} / \mathrm{Pu}$ of less than 2 .

4) Only one can shall be allowed to be in transit at any time within Vault \#4.

5) The $2736-Z$ building and the Vault $\# 4$ cubicles shall be seismically qualified.

6) The criticality firefighting category for this area shall be category $\mathrm{C}$.

7) No reportable quantity of fissile material will be stored within $183 \mathrm{~cm} \mathrm{(6} \mathrm{ft)} \mathrm{of} \mathrm{the} \mathrm{external}$ (east) wall of Vault \#4.

8) Cubicles on the south wall of Vault \#3, which is the wall shared with Vault \#4, shall be left vacant.

\subsection{DESCRIPTION OF SYSTEM AND FACILITY}

The 2345-Z Building, more commonly referred to as the Plutonium Finishing Plant (PFP), is located in the 200 West area. This facility was historically used to process plutonium into oxide or metal forms. The facility is now undergoing a cleanup phase to stabilize the plutonium still stored there. The Vault $\# 4$ storage room is located in building $2736-Z$. This building is adjacent to PFP on its south side. The Vault \#4 pedestals are currently approved to hold containers with a maximum of $2.5 \mathrm{~kg}$ of $\mathrm{PuO}_{2}$.

There are 68 cubicles in the vault. The internal dimensions of each cubicle are $61 \mathrm{~cm}$ wide (24 in.) in width and $30 \mathrm{~cm}$ (12 in.) in depth. The walls of each cubicle, including the door, are $20 \mathrm{~cm}(8 \mathrm{in}$.) thick concrete. Figure 1 shows a cross-sectional view of a cubicle Inside each cubicle are two racks, one on either side, with 14 pedestals attached to each rack. Each side of a rack has 7 pedestals, staggered between the two sides as shown in Figure 2. The vertical distance between pedestals on each side is $30 \mathrm{~cm}$ (12 in.). The horizontal, center-to-center distance between the columns is $19 \mathrm{~cm}$ ( $7.5 \mathrm{in}$.). The 28 pedestals in each cubicle are designed to hold cans with a diameter of $10.8 \mathrm{~cm}$ (4.25 in.), fitted with a magnetic security plate on the bottom of each can. 
HNF-SD-SQA-CSA-522 Rev. 0

Figure 1 Cross-Section of Cubicle
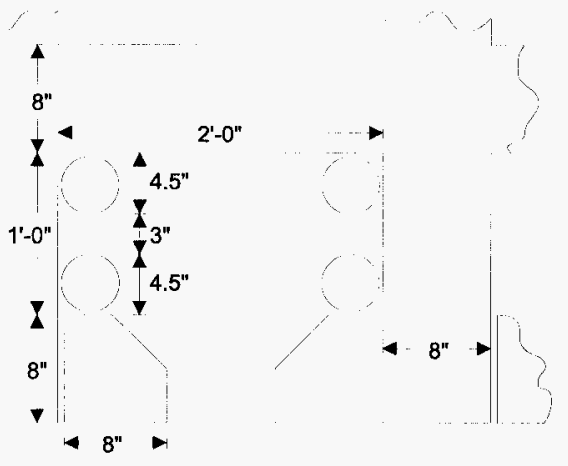

Figure 2 Rack Arrangement

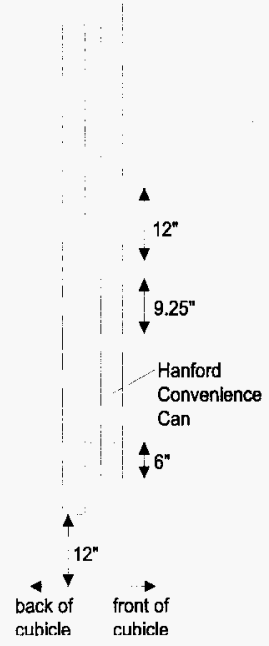


The cubicles are arranged in rows running east and west. There are ten cubicles on the north and south walls. The cubicles in the middle of the room are arranged in rows, back-to-back, 8 cubicles long. For each cubicle in the middle of the room, there is another cubicle directly opposite, $91 \mathrm{~cm}$ (36 in.) away. Figure 3 shows the layout of Vault \#4.

Figure 3 Vault \#4 Room Layout

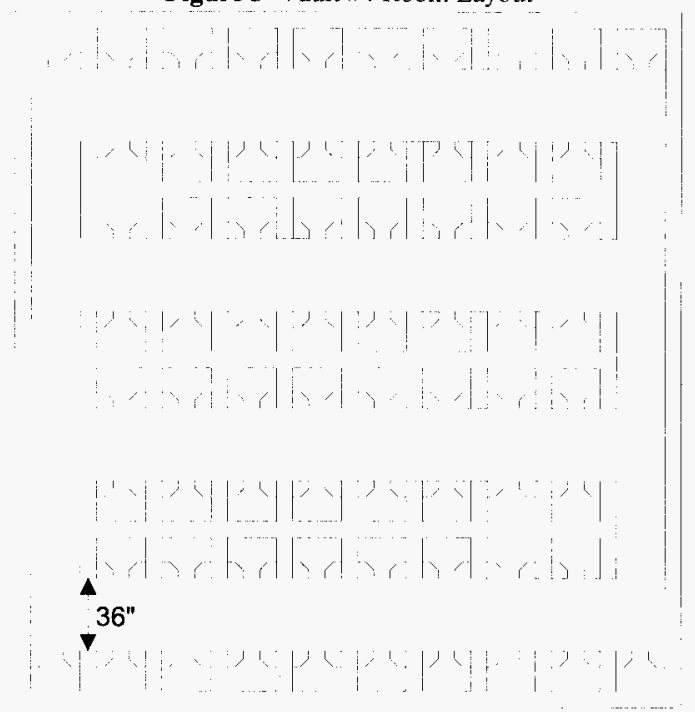

North of Vault \#4 is Vault \#3, which contains cubicles of the same design and arrangement as that in Vault \#4, and is used to store quantities of up to $2.5 \mathrm{~kg}$ of plutonium on each pedestal in every cubicle.

The west wall is shared with a hallway, through which fissile material may occasionally pass. All other rooms near Vault $\# 4$ are separated by at least two $20 \mathrm{~cm}$ ( 8 in.) walls of concrete and at least a hallway or the space between the $2736-Z$ building and the $2736-Z B$ building. East of the $2736-Z$ building is the $2731-Z$ building.

The plutonium will be quadruple canned before it is brought into the vault. The cans are made of steel, and have a wall thickness of approximately $0.023 \mathrm{~cm}(0.009 \mathrm{in}$.). The dimensions of the four cans can be found in Table 1. It was later found that the total height would be $24.1 \mathrm{~cm}$ ( $9.5 \mathrm{in}$.) rather than the $23.5 \mathrm{~cm}$ (9.3 in.) mentioned in Table 1. However, since the plutonium geometry is set by the size of the inner can, and the spacing is fixed by the pedestals, the results of this analysis are equally applicable to the taller $(24.1 \mathrm{~cm})$ cans. 
Table 1. Can Dimensions.

\begin{tabular}{|l|c|c|c|c|}
\hline Can & $\mathrm{OD}(\mathrm{cm})$ & $\mathrm{H}(\mathrm{cm})$ & $\mathrm{OD}(\mathrm{in})$ & $\mathrm{H}(\mathrm{in})$ \\
\hline \hline Inner & 8.7 & 20.3 & 3.4 & 8.0 \\
\hline Secondary & 9.2 & 21.0 & 3.6 & 8.3 \\
\hline Tertiary & 10.3 & 22.9 & 4.1 & 9.0 \\
\hline Outer & 10.8 & 23.5 & 4.3 & 9.3 \\
\hline
\end{tabular}

\subsection{METHODOLOGY}

Appendix A provides a standardized summary for the documentation (Maklin 1992, Miller 1994) of the validation carried out for the MONK6B Monte Carlo code and its predecessor versions as applicable to plutonium materials encountered at PFP. With the cross-section library supplied, the MONK6A/6B validation calculations indicate an allowed maximum k-effective $\left(\mathrm{k}_{\mathrm{eff}}\right)$ value of 0.935 for new system calculations to assure subcriticality with an acceptable margin, including the uncertainties in the analytical methods and benchmark experimental data.

\subsection{EVALUATION AND RESULTS}

\subsection{MODEL DESCRIPTION AND ASSUMPTIONS}

For the purposes of this analysis, the metal of the cans is not included except where explicitly stated otherwise. This is conservative because the metal acts as an absorber. The analysis of section 6.2.3 was done to confirm that this is indeed the case. Each HCC is filled with $4.5 \mathrm{~kg}$ of plutonium in $\mathrm{PuO}_{2}\left(5.1 \mathrm{~kg} \mathrm{PuO}_{2}\right)$. This is conservative since it is more than the normal maximum loading of $4.4 \mathrm{~kg}$ of plutonium $\left.(5.0 \mathrm{~kg} \mathrm{PuO})_{2}\right) . \mathrm{H}_{2} \mathrm{O}$ is added to produce an $\mathrm{H} / \mathrm{Pu}$ ratio of 2, which is conservative because each can is tested for moisture content after being dried at about $1000^{\circ} \mathrm{C}$.

The assumed Pu density is $5.5 \mathrm{~g} / \mathrm{cm}^{3}$. According to ARH-600 (Carter, 1968), if plutonium metal is burned, the resulting $\mathrm{PuO}_{2}$ has a density of $5.3 \mathrm{~g} / \mathrm{cm}^{3}$. However, CSER 95-005

Addendum 1 (Geiger, 1995) for the vertical calciner allows the plutonium product density to be as high as $5.5 \mathrm{~g} / \mathrm{cc}$. The plutonium is also assumed to be pure ${ }^{239} \mathrm{Pu}$. In reality most of the plutonium at PFP will have more than $5 \mathrm{wt} \%{ }^{240} \mathrm{Pu}$, but there does exist some plutonium at PFP that has less than $3 w t \%{ }^{240} \mathrm{Pu}$. Using pure ${ }^{239} \mathrm{Pu}$ is conservative.

For the purposes of this evaluation, it was conservatively assumed that the volume of $\mathrm{PuO}_{2}$, with $\mathrm{H}_{2} \mathrm{O}$ added at an $\mathrm{H} / \mathrm{Pu}$ ratio of 2 , is equal to the original volume of the plutonium at a density of $5.5 \mathrm{~g} / \mathrm{cm}^{3}$. This gives a material density of $6.65 \mathrm{~g} / \mathrm{cm}^{3}$. 
The $\mathrm{PuO}_{2}$ is modeled as a cylinder with a diameter of $8.6858 \mathrm{~cm}(3.4196 \mathrm{in}$.), which is the inner diameter of the inner can. Based on a material density of $6.65 \mathrm{~g} / \mathrm{cm}^{3}$ and a Pu mass of $4.5 \mathrm{~kg}$, the height of the $\mathrm{PuO}_{2}$ was modeled as $13.809 \mathrm{~cm}$ (5.4368 in.). Each can contains $4.5 \mathrm{~kg}$ of plutonium in $\mathrm{PuO}_{2}$ with $\mathrm{H}_{2} \mathrm{O}$ added at an $\mathrm{H} / \mathrm{Pu}$ ratio of 2 .

The vault is modeled as an infinite array of cubicles, with each cubicle having other cubicles on the sides and back, and a $91.44 \mathrm{~cm}$ (36 in.) walkway between a given cubicle and the one opposite it. Figure 4 shows the base model used when the doors of all vaults are closed. To simulate the infinite array, the unit shown in Figure 4 has periodic boundary conditions on four sides. This allows for more manageable calculations, whereas the reactivity of the room should not be significantly less than that of the infinite array. The floor is $20.32 \mathrm{~cm}$ ( 8 in. thick) concrete, and the cubicle is modeled as being $254 \mathrm{~cm}$ ( $8 \mathrm{ft} 4 \mathrm{in}$.) tall. At the top of the model is a $2.54 \mathrm{~cm}$ ( 1 in.) water reflector used to account for various objects, including the ceiling, that might provide further reflection above the top of the cubicle.

Figure 4 Unit Cell of Model

(Closed Doors)
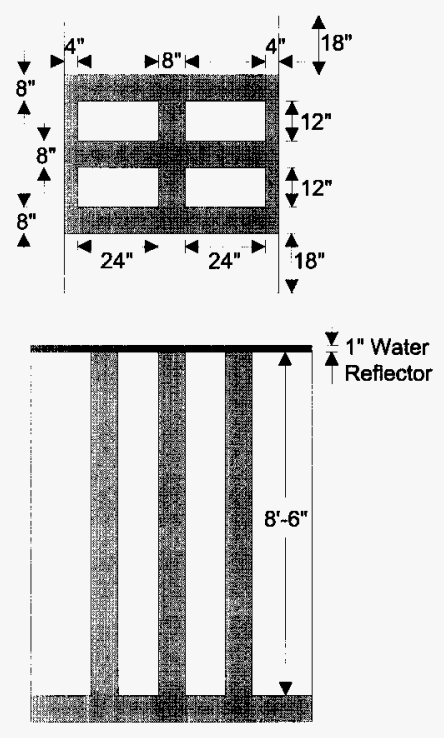

As discussed in section 6.2 .1 , to fill all 68 cubicles with 28 cans, each can with $4.4 \mathrm{~kg}$ of plutonium was found to be unacceptable. Therefore, except as discussed in section 6.2.1, calculations were done for the arrangement shown in Figure 5, where half the cubicles are left vacant. 
Figure 5 Storage Arrangement

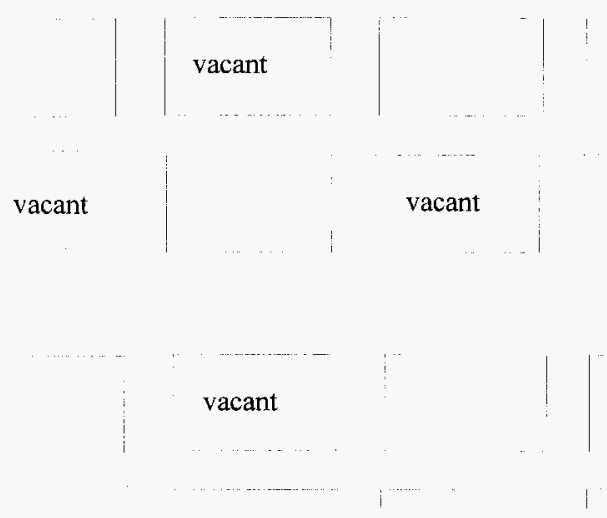

\subsection{NORMAL CONDITIONS}

For normal conditions, the following variables were considered: storage density, water content of concrete, steel around the cans, cubicle doors open and closed, position of the inner can within each $\mathrm{HCC}$ unit, and changes in reactivity as a person moves a can around within a cubicle, including the presence of a person's body and hands. Each of these variables are covered in the sections following.

\subsubsection{Storage Density}

CSER 79-028 (Chiao, 1979) authorizes storage of up to $2.5 \mathrm{~kg}$ of material on each of the 28 pedestals in each cubicle of Vaults \#3 and \#4. This amounts to $70 \mathrm{~kg}$ of material per cubicle. These limits are based on the analysis in CSER 78-022 (R. Carter, 1978), which allows for the storage of up to $2.5 \mathrm{~kg}$ of material on each of 35 pedestals in each cubicle of Vault \#1, amounting to $87.5 \mathrm{~kg}$ per cubicle. This analysis is intended to allow for the storage of cans containing up to $4.4 \mathrm{~kg}$ of plutonium. To store 28 cans in every cubicle, each can with $4.4 \mathrm{~kg}$ of plutonium, would result in a storage density of $123.2 \mathrm{~kg}$ per cubicle.

Case cfull is a case in which every cubicle is filled with 28 cans of $4.5 \mathrm{~kg}$ of plutonium each. The result of this calculation is a $\mathrm{k}_{\mathrm{eff}} \pm 1 \sigma$ of $1.079 \pm 0.003$, indicating that the storage density of a fully loaded vault would not be acceptable. As a consequence, a storage arrangement in which every other cubicle as shown in Figure 5 above was analyzed. Case cskip, which uses the storage arrangement shown in Figure 5, gives a $k_{\text {eff }} \pm 1 \sigma$ of $0.858 \pm 0.003$. Accordingly, all further analysis was done for the arrangement shown in Figure 5. 
Table 2. Storage Density Effect

\begin{tabular}{||l|l|l|l||}
\hline Case & Description & $\mathrm{k}_{\mathrm{eff}}$ & \pm 10 \\
\hline \hline cfull & Every cubicle filled with 28 cans, each can with $4.5 \mathrm{~kg}$ plutonium & 1.079 & 0.003 \\
\hline cskip & $\begin{array}{l}\text { Every other cubicle filled with } 28 \text { cans, each can with } 4.5 \mathrm{~kg} \\
\text { plutonium }\end{array}$ & 0.858 & 0.003 \\
\hline
\end{tabular}

\subsubsection{Water Content and Density of Concrete}

The water content of concrete can have varying effects on reactivity. As the water content increases, reactivity may rise due to the increase in moderation and/or the increase in reflectivity of the concrete. As water decreases, moderation and reflection is lost, but with this comes an increase in interaction between cubicles, which can raise reactivity. The lowest water content considered was $2.77 \mathrm{wt} \%$ water $(0.31 \mathrm{wt} \%$ hydrogen), which corresponds to end-of-life for temperatures of around $100^{\circ} \mathrm{C}$ for "Hanford ordinary concrete" (L. Carter, 1983). The highest water content considered was $8.94 \mathrm{wt} \%$ water ( $1.0 \mathrm{wt} \%$ hydrogen), for Portland cement (ARH-600). It was found that the lower water concrete was the most conservative and thus it was used in all subsequent calculations. Although the extremely low water content is not credible under normal conditions, it is used because it conservatively bounds low water content.

A subsequent calculation was done to show the effect of changes in concrete density that may arise due to air bubbles in the concrete due to improper casting. This was done using the lower water content of case cskip, but with the concrete density reduced by $10 \%$. Although the lower density concrete gives a slightly higher $\mathrm{k}_{\text {eff }}$, the already low water content of the concrete used is considered conservative enough to bound this analysis.

Table 3. Water Content and Density of Concrete Effect on Reactivity

\begin{tabular}{|l|l|l|l|l|l||}
\hline Case & Concrete & wt\% water & Density $\left(\mathrm{g} / \mathrm{cm}^{3}\right)$ & $\mathrm{k}_{\mathrm{eff}}$ & \pm 10 \\
\hline \hline cskip & Hanford ordinary & 2.77 & 2.26 & 0.858 & 0.003 \\
\hline cport & Portland & 8.94 & 2.30 & 0.833 & 0.003 \\
\hline clowdens & Hanford ordinary & 2.77 & 2.03 & 0.865 & 0.003 \\
\hline
\end{tabular}

\subsubsection{Steel Around Cans}

The plutonium will be quadruple canned before it is brought into the vault. The cans are made of steel, and have a wall thickness of approximately $0.023 \mathrm{~cm}(0.009 \mathrm{in}$.). The steel of the four cans can contribute to isolation from other cans and self reflection. To evaluate these two 
effects, cases were run both with and without $0.091 \mathrm{~cm}(0.036 \mathrm{in}$.) thick stainless steel encasing the plutonium oxide. The $0.091 \mathrm{~cm}(0.036 \mathrm{in}$.) of stainless steel is used to represent the four layers of cans, each $0.023 \mathrm{~cm}(0.009 \mathrm{in}$.) thick. Additionally, three cases were run to show the effects of various thicknesses of lead shielding. As the results below indicate, the presence of the metal cans or lead shielding has negligible effect on reactivity, and will not be included in further analysis.

Table 4. Steel of Can and Lead Shielding Effect on Reactivity

\begin{tabular}{||l|l|l|l||}
\hline Case & Description & $\mathrm{k}_{\text {eff }}$ & $\pm 1 \sigma$ \\
\hline \hline cskip & Bare $\mathrm{PuO}_{2}$ & 0.858 & 0.003 \\
\hline ccans & Encased in $0.091 \mathrm{~cm}(0.036 \mathrm{in.})$ of steel & 0.853 & 0.003 \\
\hline clead16 & Encased in $0.159 \mathrm{~cm}(0.0625 \mathrm{in}$.$) of lead$ & 0.864 & 0.003 \\
\hline clead8 & Encased in $0.318 \mathrm{~cm}(0.125 \mathrm{in.})$ of lead & 0.864 & 0.003 \\
\hline clead & Encased in $0.635 \mathrm{~cm}(0.250 \mathrm{in.}$ ) of lead & 0.859 & 0.003 \\
\hline
\end{tabular}

\subsubsection{Cubicle Doors Open/Closed}

The doors consist of two concrete columns, with outer dimensions of $20 \mathrm{~cm} \mathrm{x} 20 \mathrm{~cm} \mathrm{x}$ $100 \mathrm{~cm}(8 \mathrm{ft} \times 8 \mathrm{ft} \times 7 \mathrm{ft} 6 \mathrm{in}$.) and are mounted such that they leave a $15 \mathrm{~cm}(6 \mathrm{in}$.) gap beneath them. When the doors are closed, moderation and reflection are increased. When open, interaction between cells across the hallway is possible. The cases in Table 5 show the effect of the doors. Although a $20 \mathrm{~cm}(8 \mathrm{in}$.) gap exists between the concrete sections of the doors even when closed, the case used to represent closed doors considers complete blockage of the entrance to the vauit, thus eliminating the gap between and beneath the doors.

For each of the cases of doors open and closed for a two dimensional array of cubicles, a second calculation was made in which a single infinitely long row of back-to-back cubicles was analyzed to show the amount of interaction across rows in each case. As indicated in Table 5, the interaction across rows is significant when the doors are open, but with the total concrete thickness of $41 \mathrm{~cm}(16 \mathrm{in}$.) the doors provide substantial isolation between rows when closed. As shown in section 6.2 .3 above, as water content in the concrete rises, the isolating effect brings reactivity down further. By opening the doors, the interaction across the walkway is not increased enough to compensate for the loss of reflection from the concrete in the doors. Figure 4 above shows the model used for the doors closed. Figure 6 below shows the model used for doors open. 
Figure 6 Model for Doors Open (obase)
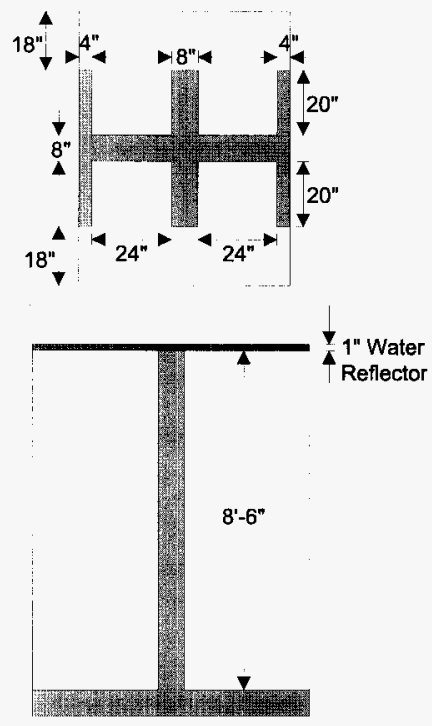

Table 5. Cubicle Door's Effect on Reactivity

\begin{tabular}{||l|l|l|l|l||}
\hline \hline Case & Doors & Number of back-to-back rows & $\mathrm{k}_{\mathrm{eff}}$ & \pm 10 \\
\hline \hline cskip & Closed & infinite & 0.858 & 0.003 \\
\hline cl row & Closed & 1 & 0.815 & 0.003 \\
\hline obase & Open & infinite & 0.836 & 0.003 \\
\hline ol row & Open & 1 & 0.635 & 0.003 \\
\hline
\end{tabular}

\subsubsection{Position of Inner Can Within Unit}

Although the outer can's position is fixed when placed on a pedestal, the inner can could move as much as $0.96 \mathrm{~cm}(0.38 \mathrm{in}$.) within the outer can. Figure 7 below shows the different 
positions of the inner can that were considered. Case cskip considers an inner can centered within the unit. Case c12cent places the inner cans on either side of each rack closer to the cans on the opposite side of the rack. Case $\mathrm{c} 12$ far separates cans on either side of the rack from cans on the opposite side of the rack. For case c12cent, the cans are moved further from the concrete door and back wall, whereas case c12far brings the cans closer to the concrete door and back wall. Case cclse $2 x$ moves the cans closer to the concrete wall upon which the rack is mounted. These cases were run with the doors of the cubicle closed as described in section 6.2.4. Results indicate that the position of the inner can within the unit has little affect on reactivity. All subsequent calculations position the inner can within the center of the unit unless specified otherwise.

Table 6. How Inner Can Position in Unit Effects Reactivity

\begin{tabular}{|l|l|l|l||}
\hline Case & Position of inner can within unit & $\mathrm{k}_{\text {eff }}$ & $\pm 1 \sigma$ \\
\hline \hline cskip & Centered & 0.858 & 0.003 \\
\hline c12cent & Moved towards cans on other side of rack & 0.848 & 0.003 \\
\hline c12far & Moved away from cans on other side of rack & 0.854 & 0.003 \\
\hline cclse2x & Moved towards wall which the rack is mounted on & 0.849 & 0.003 \\
\hline
\end{tabular}

Figure 7 Positions of Inner Cans

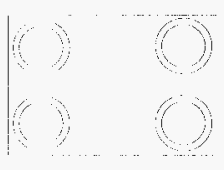

cskip

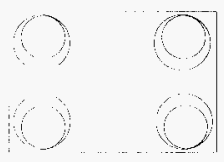

cl2far

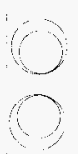

c12cent

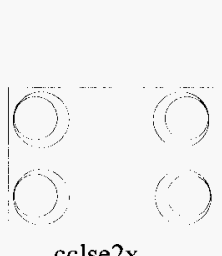

cclse $2 \mathrm{x}$

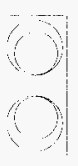

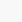




\subsubsection{Person Moving a Can Within Cubicle Interior}

Only one container will be allowed to be in transit at one time within Vault \#4. When the doors are open, a person may stand in the doorway, while positioning the can anywhere in the cubicle. The worst case position of this can in transition is assumed to be between the two columns of cans on a rack, level to the center can in one of the columns as illustrated in Figure 8. Case oxlevel considers a can in this position while the doors are open. Because the model uses an infinite array, this case (as well as all others in this section with a can in transit) is actually modeled as having an additional can in transit in half of the cubicles being utilized for storage (one side of each row).

Figure 8 Worst Case Position of

Can in Transit

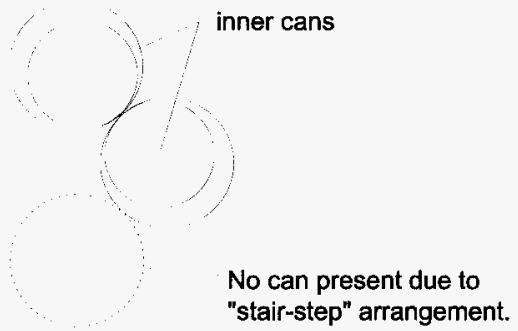

Also, the effects of the presence of a person and the person's hand on reactivity was analyzed. The presence of a person was modeled by replacing the doorway with a cuboid of water $30.48 \mathrm{~cm}$ (12 in.) thick, $60.96 \mathrm{~cm}$ ( 24 in.) wide and $254 \mathrm{~cm}$ (100 in.) tall. This is far larger than the expected size of a person, but represents a conservative upper bound in terms of the additional reflection provided by a body. The drop in reactivity with the introduction of a person indicates that the reflection provided by the body does not quite compensate for the loss of interaction across the walkway due to absorption of neutrons by the body. Figure 8 shows how the presence of a body was modeled. 
Figure 9 Person in Doorway

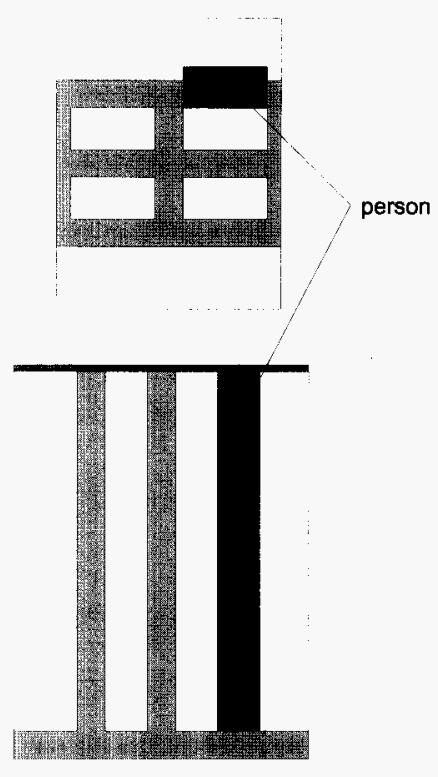

The cases ohand and ohand 2 introduce a hand that is modeled as a $2.54 \mathrm{~cm}(1 \mathrm{in}$.) reflector on the radial side of the outer can except where the cans meet. ohand includes a person in the doorway as in opindoor, whereas ohand2 does not. The introduction of the hand has mixed results, depending on whether there is a person in the doorway or not. When a person is present (ohand), reactivity goes up slightly with the introduction of the hand. When a person is not present (ohand2), reactivity goes down slightly with the introduction of the hand. The differing effects are due to an increase in reflection in ohand, and an increase in interaction in ohand2. 
HNF-SD-SQA-CSA-522 Rev. 0

Figure 10 Hand Around Can

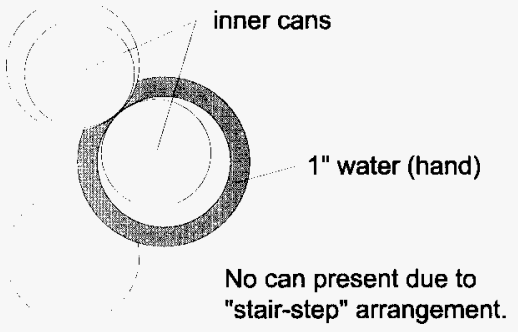

Table 7. Person Moving Can Inside Cubicle

\begin{tabular}{|l|l|l|l|l|l||}
\hline Case & Can in Transition & Body in doorway & Hand around can & $\mathrm{k}_{\text {eff }}$ & $\bullet 1 \sigma$ \\
\hline \hline obase & No & No & No & 0.836 & 0.003 \\
\hline oxlevel & Yes & No & No & 0.845 & 0.003 \\
\hline opindoor & Yes & Yes & No & 0.829 & 0.003 \\
\hline ohand2 & Yes & No & Yes & 0.840 & 0.003 \\
\hline ohand & Yes & Yes & Yes & 0.835 & 0.003 \\
\hline
\end{tabular}

\subsubsection{Storage of Fissile Material Near Vault \#4}

North of Vault \#4 is Vault \#3, which contains cubicles of the same design and arrangement as that in Vault \#4. With a $20 \mathrm{~cm}$ wall (8 in.) separating Vaults $\# 3$ and \#4, the two vaults are neutronically coupled. Vault $\# 3$ is used to store quantities of up to $2.5 \mathrm{~kg}$ of plutonium on each pedestal in every cubicle. CSER 79-028 (Chiao, 1979) covers Vaults \#3 and \#4 for $2.5 \mathrm{~kg}$ cans based on calculations using an infinite array given in CSER 78-022 (Carter, 1978). The areal density of the analysis in CSER 78-022 for $2.5 \mathrm{~kg}$ units ( $85.7 \mathrm{~kg}$ per cubicle) is greater than that of this CSER ( $61.6 \mathrm{~kg}$ per cubicle) and calculations were done using an infinite array. This bounds the total quantity of both Vault \#3 in its present configuration and Vault \#4 with the new $4.4 \mathrm{~kg}$ cans. Note also, that this CSER analyzes an infinite array of every other cubicle filled with $4.4 \mathrm{~kg}$ cans.

In the event that the wall common to both Vaults \#3 and \#4 is filled on both sides, there remains the issue that cubicles directly behind a cubicle filled with $4.4 \mathrm{~kg}$ cans will be filled with $2.5 \mathrm{~kg}$ units (cans or buttons). However, since the cubicles on this wall are currently not used in Vault $\# 3$, nor are they expected to be used, their vacancy will be made a requirement. 
The west wall is shared with the hallway. Fissile material will be present in the hallways at times as individual cans are being weighed and cans are moved about in wagons. There are no cubicles on this wall, except at the corners of the room. The analysis for a wagon inside Vault \#4 as a contingency in section 6.3 .2 bounds any activities that may take place in the hallway.

All other rooms near Vault \#4 are separated by at least two $20 \mathrm{~cm}(8 \mathrm{in}$.) walls of concrete and at least a hallway or the space between the $2736-\mathrm{Z}$ building and the 2736 -ZB building. As discussed in section 6.2 .4 , the total of $41 \mathrm{~cm}$ (16 in.) of concrete provides significant isolation. Furthermore, the analysis of this CSER was done using an infinite array, which should more than compensate for interaction with the other rooms. Therefore, no further consideration with regards to interaction with other rooms is necessary.

The east wall of Vault \#4 is an external wall. No reportable quantity of material shall be stored within $183 \mathrm{~cm}(6 \mathrm{ft})$ of the east wall.

\subsection{OFF-NORMAL CONDITIONS}

For off-normal conditions the following contingencies were considered: Overbatch, bringing a fully loaded Fixed Array Wagon into the vault, moving more than one can at a time, internal moderation, and interspersed moderation. Each of these contingencies will be covered individually in the sections following. Since no contingencies due to earthquakes are postulated, this CSER will make the seismic qualification of the building and the pedestals for the $4.4 \mathrm{~kg} \mathrm{Pu}$ cans a requirement.

The results of the interspersed moderation in section 6.3 .5 shows that water in the vault air is not a problem. Therefore, fire fighting can use water fog or foam, but not streams of water that could move a Pu can. Consequently, Vault \#4 shall be listed as a criticality fire fighting category $\mathrm{C}$.

\subsubsection{Overbatch Contingency}

The volume of the inner can is approximately 1.2 liters, and at a plutonium density of $5.5 \mathrm{~g} / \mathrm{cm}^{3}$, the can could hold approximately $6.6 \mathrm{~kg}$ of plutonium. This is equivalent to approximately $7.5 \mathrm{~kg}$ of $\mathrm{PuO}_{2}$, and is significantly more than a normal maximum loading of $4.4 \mathrm{~kg}$ of plutonium $(5.0 \mathrm{~kg} \mathrm{PuO}$ ). Since each can will be weighed before it is brought into the vault, it is highly unlikely that any cans with this much material would be brought into Vault \#4. For the overbatch analysis, a single can containing approximately $6.6 \mathrm{~kg}$ of plutonium was placed on one of the pedestals.

The pedestal upon which the overbatched can is placed is at the vertical center of one of the back columns of cans. One case was run with the doors closed (cdbatch), and another with the doors open (odbatch) with someone holding an additional can next to the overbatched can. The case odbatch also includes the presence of a hand around the can. The equivalent normal condition cases are also given for comparison. To simplify the calculational model, the 
overbatched can is actually repeated in every cubicle used for storage in case cdbatch, and in every cubicle on one side of a given row in case odbatch.

Table 8. Overbatch Contingency

\begin{tabular}{||l|l|l|l||}
\hline \hline Case & Description & $\mathrm{k}_{\mathrm{eff}}$ & \pm 10 \\
\hline \hline cskip & Normal condition, doors closed & 0.858 & 0.003 \\
\hline cdbatch & Overbatched can present, doors closed & 0.862 & 0.003 \\
\hline ohand2 & Normal condition, can being moved within cubicle, doors open & 0.840 & 0.003 \\
\hline odbatch & $\begin{array}{l}\text { Overbatched can present, can being moved within cubicle, } \\
\text { doors open }\end{array}$ & 0.848 & 0.003 \\
\hline
\end{tabular}

\subsubsection{Loaded Fixed Array Wagon Contingency}

Only one container is allowed to be in transit within Vault \#4 at any one time. $\mathrm{PuO}_{2}$ filled cans are moved either one at a time by hand or by the use of a wagon. Because security requires people to enter the vault in pairs, to exceed this limit would require an error by two people. However, the contingency of bringing a Fixed Array Wagon filled with cans into the vault is considered here.

Figure 10 shows a sketch of a typical wagon. However, the wagon was conservatively modeled and positioned as shown in Figure 12 for calculational convenience. The wagon was conservatively modeled as having six HCC cans (as opposed to the 5 cans it was designed for), each containing $4.5 \mathrm{~kg}$ of plutonium in $\mathrm{PuO}_{2}$ form. Also, the height of the wagon was adjusted to correspond to the height of the lowest cans in the rack nearest the door. The tighter packing of the wagon and its position relative to the lowest cans in the vault introduces some additional conservatism. An extra can was positioned in the worst case location within the vault for a total of seven additional cans. The door was modeled as open to allow maximum interaction between the wagon and the cans in the vault.

Table 9. Fixed Array Wagon in Vault Contingency

\begin{tabular}{||l|l|l|l||}
\hline Case & Description & $\mathrm{k}_{\text {eff }}$ & $\pm 1 \mathrm{o}$ \\
\hline \hline oxlevel & Extra can in transition in vault, doors open & 0.845 & 0.003 \\
\hline owagon & $\begin{array}{l}\text { Filled Fixed Array Wagon in doorway, extra can in } \\
\text { transition, doors open }\end{array}$ & 0.851 & 0.003 \\
\hline
\end{tabular}


HNF-SD-SQA-CSA-522 Rev. 0

Figure 11 Sketch of Fixed Array Wagon
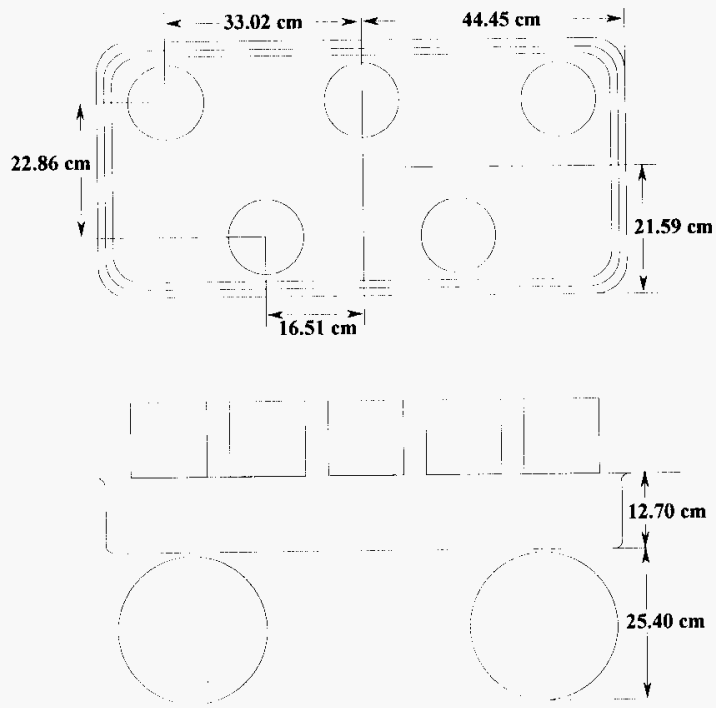
HNF-SD-SQA-CSA-522 Rev. 0

Figure 12 Model of Fixed Array

Wagon in Vault

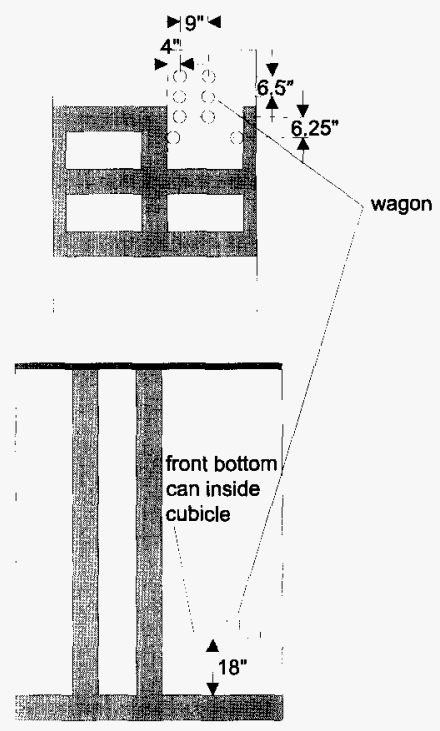

\subsubsection{Additional Can Contingency}

Each cubicle in use has enough pedestals to hold 28 cans. Cans left places other than on a pedestal are not allowed, except for one can that is allowed to be in transit in the vault at a time. Because security requires people to enter the vault in pairs, to exceed this limit would require an error by two people. However, both a case where a can is left on the floor, and a case of moving two cans around at a time within a cubicle were considered.

The case cfloor placed a can just below one of the back two columns of cans, which are the columns with the bottom can positioned closest to the floor of the vault. In the analysis the vault doors were closed. As can be seen, the presence of a single additional can on the floor has negligible effect on reactivity. The cases $02 x t r a c$ and $02 x$ tra both place two cans in contact with a can near the front of the door as shown in Figure 13 below, with the doors open. In the case of $02 x t r a c$, the inner cans are centered within the unit, and in the case of $02 x$ tra, two of the inner cans are moved as close to each other as possible, and the third can is moved closer to both of the other inner cans. Again, the increase in reactivity is small if not negligible. 
HNF-SD-SQA-CSA-522 Rev, 0

Table 10. Additional Can in Cubicle Contingency

\begin{tabular}{||l|l|l|l||}
\hline Case & Description & $\mathrm{k}_{\text {eff }}$ & $\pm 1 \sigma$ \\
\hline \hline cskip & Normal condition, doors closed & 0.858 & 0.003 \\
\hline cfloor & Extra can on floor, doors closed & 0.859 & 0.003 \\
\hline oxlevel & Normal condition, one can in transit, doors open & 0.845 & 0.003 \\
\hline o2xtrac & Two cans in transit, inner cans centered within unit, doors open & 0.849 & 0.003 \\
\hline o2xtra & Two cans in transit, cans moved closer together, doors open & 0.850 & 0.003 \\
\hline
\end{tabular}

Figure 13 Two Cans in Transit

Contingency

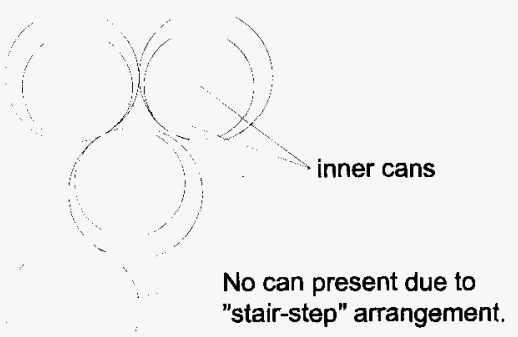

\subsubsection{Internal Moderation Contingency}

The material placed into the cans is dry $\mathrm{PuO}_{2}$. Dry in this case means the $\mathrm{H} / \mathrm{Pu}$ ratio is less than 2. In practice, the $\mathrm{H} / \mathrm{Pu}$ will be much less than 2 , as each can is tested for moisture content after being dried at about $1000^{\circ} \mathrm{C}$. Since each unit is quadruple canned, water could not enter the innermost can during fire fighting, or other scenarios of this nature. Therefore, the contingent condition would be to have one can with $\mathrm{H} / \mathrm{Pu}>2$ placed into the storage cubicle.

Optimizing internal moderation in a single can will have little effect on the reactivity of the whole system, just as indicated by the case of overbatching a single can in section 6.3.1 and for optimal internal moderation of a single can in the CSER for vault \#2 (Erickson 1996). Rather than conducting a complete parametric study, only the limiting case from the CSER for vault \#2 was analyzed, with a few additional cases run to verify the same trend, and to extend the range to 
an $\mathrm{H} / \mathrm{Pu}$ ratio of 635 . The limiting case was one in which nearly all of the interstitial volume of the $\mathrm{PuO}_{2}$ is filled with water, resulting in an $\mathrm{H} / \mathrm{Pu}$ ratio of 4 . The $\mathrm{k}_{\mathrm{eff}} \pm 1 \sigma$ for this case (cint4) is $0.868 \pm 0.003$.

Table 11. Internal Moderation Contingency

\begin{tabular}{|l|l|l|l|}
\hline Case & H/Pu ratio & $k_{\text {eff }}$ & $\pm 1 \sigma$ \\
\hline \hline oxlevel & 2.00 & 0.845 & 0.003 \\
\hline cint3 & 3.00 & 0.857 & 0.003 \\
\hline cint4 & 4.00 & 0.868 & 0.003 \\
\hline cint5p14 & 5.14 & 0.857 & 0.003 \\
\hline cint18p4 & 18.4 & 0.844 & 0.003 \\
\hline cint60p9 & 60.9 & 0.848 & 0.003 \\
\hline cint157 & 157 & 0.846 & 0.003 \\
\hline cint316 & 316 & 0.848 & 0.003 \\
\hline cint635 & 635 & 0.840 & 0.003 \\
\hline
\end{tabular}

\subsubsection{Interspersed Moderation Contingency}

A parametric analysis of the water density in the vault was used to asses the contingency of water fog or steam for incidents such as fire. Results at water densities between $0 \%$ and $100 \%$ of full density were computed to find the most reactive density. The results of the study can be found in Table 12. It was found that reactivity changes very little up to $0.05 \mathrm{~g} / \mathrm{cm}^{3}$. At densities greater than $0.05 \mathrm{~g} / \mathrm{cm}^{3}$, the reactivity begins to drop, until it reaches 0.761 at full water density. Figure 14 is a graph of $\mathrm{k}_{\text {eff }}$ vs interspersed water moderation density. Introduction of water by firefighting or other means would not significantly affect the criticality safety of the storage vault. 
HNF-SD-SQA-CSA-522 Rev. 0

Table 12. Interspersed Moderation Contingency

\begin{tabular}{|l|l|l|l||}
\hline Case & Interspersed water density $\left(\mathrm{g} / \mathrm{cm}^{3}\right)$ & $k_{\text {eff }}$ & \pm 10 \\
\hline \hline cskip & 0.0 & 0.858 & 0.003 \\
\hline cp00001 & 0.00001 & 0.850 & 0.003 \\
\hline cp00002 & 0.00002 & 0.849 & 0.003 \\
\hline cp00005 & 0.00005 & 0.852 & 0.003 \\
\hline cp0001 & 0.0001 & 0.854 & 0.003 \\
\hline cp0002 & 0.0002 & 0.859 & 0.003 \\
\hline cp0005 & 0.0005 & 0.853 & 0.003 \\
\hline cp001 & 0.001 & 0.852 & 0.003 \\
\hline cp002 & 0.002 & 0.854 & 0.003 \\
\hline cp005 & 0.005 & 0.851 & 0.003 \\
\hline cp01 & 0.01 & 0.848 & 0.003 \\
\hline cp02 & 0.02 & 0.851 & 0.003 \\
\hline cp05 & 0.05 & 0.847 & 0.003 \\
\hline cpI & 0.1 & 0.832 & 0.003 \\
\hline cp2 & 0.2 & 0.803 & 0.003 \\
\hline cp5 & 0.5 & 0.763 & 0.003 \\
\hline c1 & 1.0 & 0.761 & 0.003 \\
\hline \hline
\end{tabular}


HNF-SD-SQA-CSA-522 Rev. 0

Figure $14 k_{\text {eff }} \pm 1 \sigma$ as a Function of Interspersed Water Density

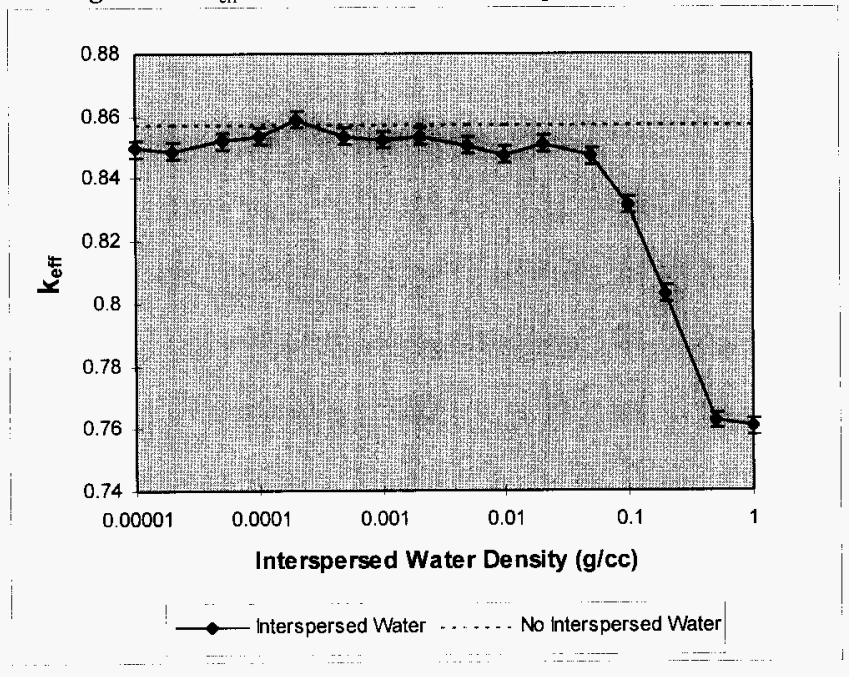




\subsubsection{Person Falling into Cubicle}

One case was run for the contingency of a person falling into the cubicle. The person is modeled as being a cuboid of water $244 \mathrm{~cm}(8 \mathrm{ft})$ tall, $61 \mathrm{~cm}(2 \mathrm{ft})$ wide, and $38 \mathrm{~cm}(15 \mathrm{in}$.) thick. Again, this is an excessively large person, but should be bounding. The $\mathrm{k}_{\mathrm{eff}} \pm 1 \sigma$ for this case (opincell) is $0.806 \pm 0.003$, indicating that the isolation between sides of the cubicle provided by the person's body lowers reactivity.

\subsection{REFERENCES}

Carter, L. L., 1983, "Bulk Shield Design for Neutron Energies Below $50 \mathrm{MeV}$, Nuclear Technology/Fusion, Vol. 3, Mar. 1983, American Nuclear Society.

Carter, R. D., G. R. Kiel and K. R. Ridgeway, 1968, Criticality Handbook, ARH-600, June 30 1968 plus updates, Atlantic Richfield Hanford Company, Richland, Washington.

Carter, R. D., 1978, Criticality Safety Analysis Report for Criticality Prevention Specification 80.10-2, Room 1, 2736-Z Building, CSAR 78-022, Rockwell Hanford Company, Richland, Washington.

Chiao, T., 1979, Criticality Safety Analysis Report For RHO-MA-165, Criticality Prevention Specification 80.10, Out of Hood Storage (Rooms 3 and 4, 2736-Z Only), CSAR 79-028, Rockwell Hanford Company, Richland Washington.

Geiger, J. L., 1995, CSER 95-005 Addendum 1 Stainless Steel Insulation, WHC-SD-SQA-CSA-20404, Rev. 0, Westinghouse Hanford Company, Richland, Washington.

Macklin, L. L., and E. M. Miller, 1992, CCVR 91-001; MONK6A Pu Validation, WHC-SD-SQA-CSWD-20015, Rev. 0, Westinghouse Hanford Company, Richland, Washington.

Miller, E. M., 1994, CCVR 94-001; MONK6B Pu Validation, WHC-SD-SQA-CSWD-20019, Rev. 0, Westinghouse Hanford Company, Richland, Washington.

WHC, Nuclear Criticality Safety Manual, WHC-CM-4-29, Westinghouse Hanford Company, Richland, Washington. 
HNF-SD-SQA-CSA-522 Rev. 0

APPENDIX A

INDEPENDENT REVIEW COMMENTS AND CHECKLIST

A-1 
HNF-SD-SQA-CSA-522 Rev. 0

\section{Reviewer's Comments - K. N. Schwinkendorf}

This document was reviewed for technical content only; computer input/output files were checked by another reviewer. The results documented in this report are consistent with earlier results from the R. D. Carter reference. Although some trends were different (such as whether cans were more reactive with or without the steel can material being present), the differences themselves were within the statistical uncertainties in the calculation. Other reported parametrics made sense (e.g., increased reactivity with decreased concrete density).

There appears to be a large margin between the normal cases and the criticality safety limit, with very negligible increases for the off-normal conditions (almost all cases were $k_{\text {eff }}<0.9$ ). This suggests that if required, increased loading of cans may be realized, once additional analysis is performed. This analysis supports the planned loading of $\mathrm{PuO}_{2}$ in cans as specified in the CSER. 
HNF-SD-SQA-CSA-522 Rev. 0

\section{CHECKLIST FOR INDEPENDENT REVIEW}

Document Reviewed: CSER 96-025: PFP Storage of 9.25 inch Ta $11.4 .4 \mathrm{~kg}$ Pu Cans on Existing Vault 4. Pedestals

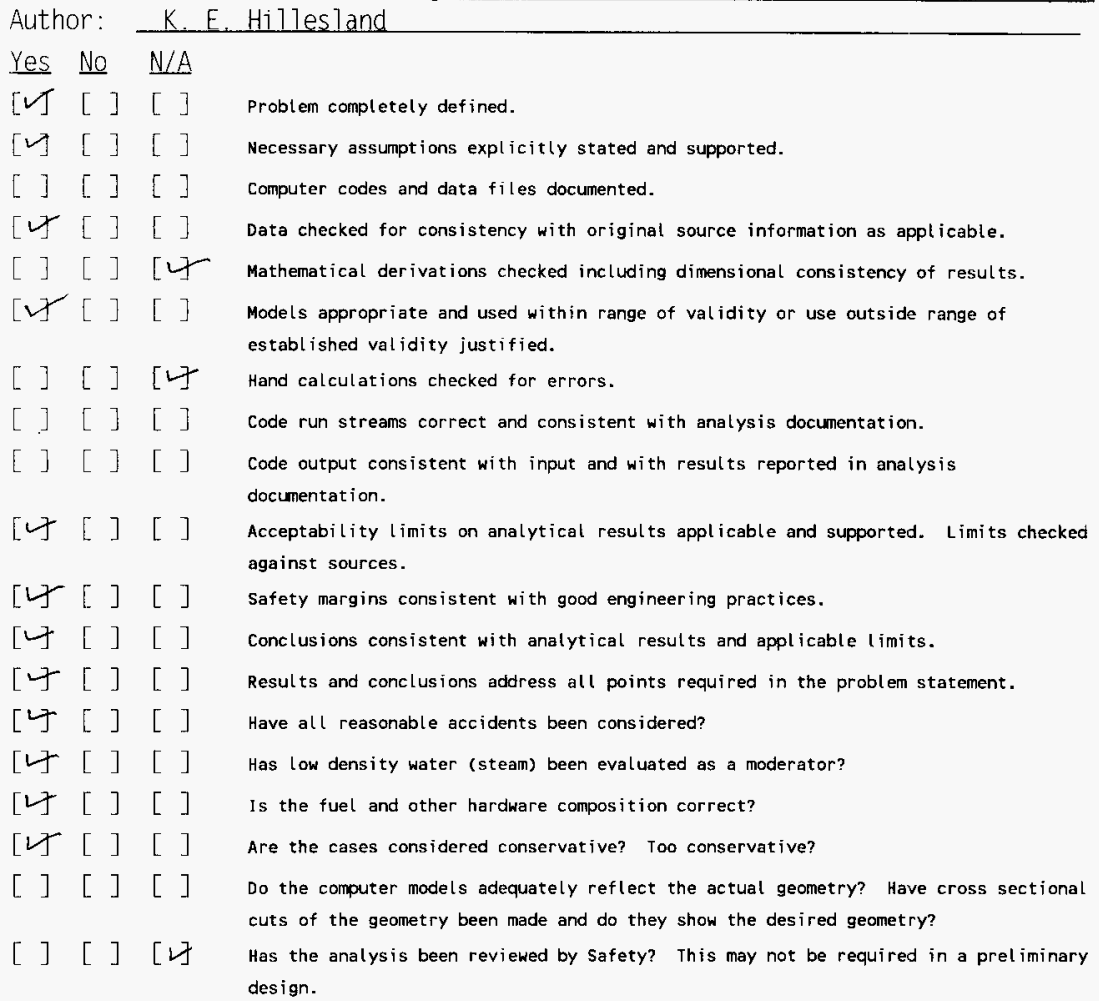

[U] [] [] Has the reviewer completed the Criticality Safety Course for Managers and Engineers? Date completed $5 / 7 / 96$

Reviewed by: KK.n. Scluwinkendy Date $1 / 10 / 97$

NOTE: Any hand calculations, notes, or summaries generated as part of this review should be signed, dated, and attached to this checklist. Materials should be labeled and recorded so that it is intelligible to a technically-qualified third party. 
HNF-SD-SQA-CSA-522 Rev. 0

\section{CHECKLIST FOR INDEPENDENT REVIEW}

Document Reviewed: CSER 96-025: PFP Storage of 9.25 inch Ta71. $4.4 \mathrm{~kg}$ Pu Cans on Existing Vault 4 Pedestals

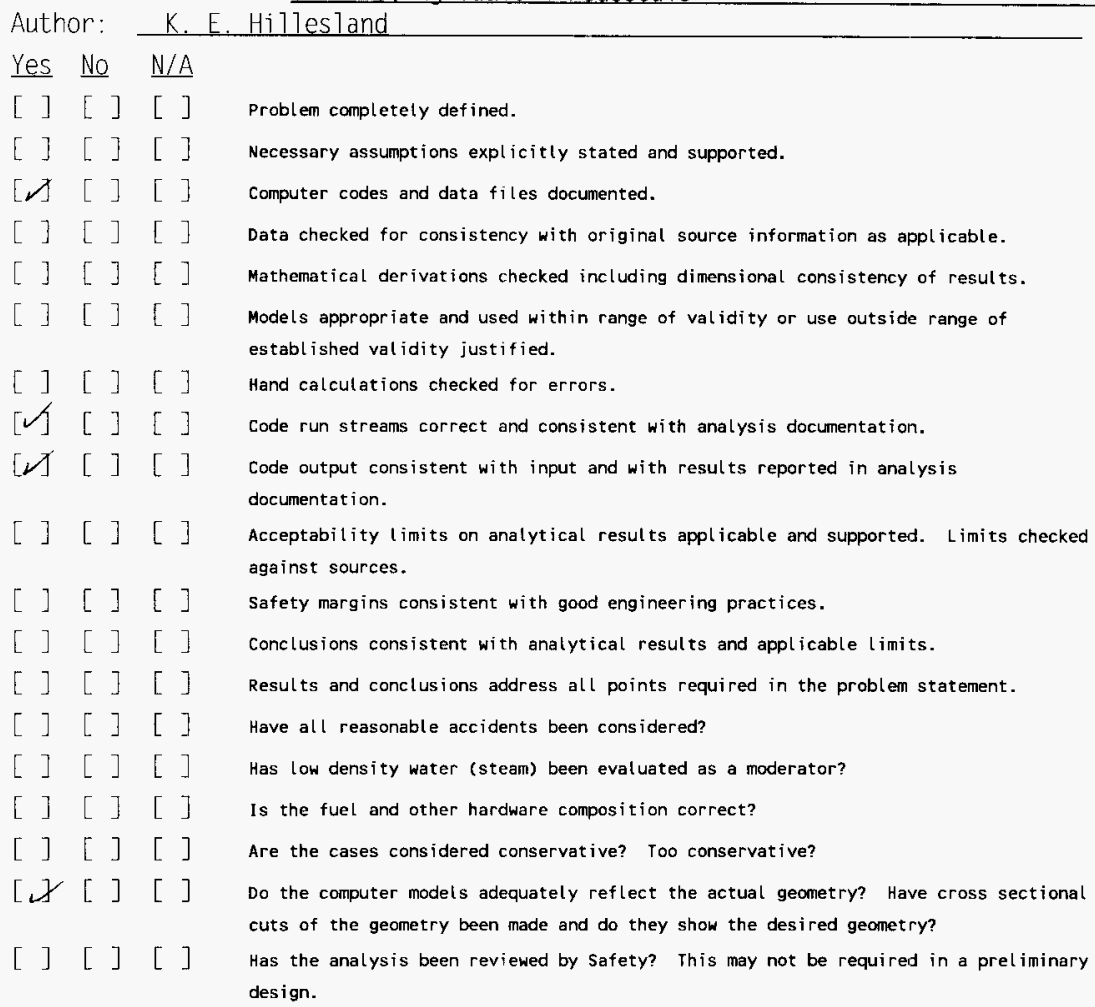

[ ] $[\sqrt{ }] \quad[] \quad$ Has the reviewer completed the Criticality Safety Course for Managers and Engineers? Date completed

Reviewed by: Rokut N. Paha Date $1 / 10 / 97$

NOTE : Any hand calculations, notes, or sumaries generated as part of this review should be signed, dated, and attached to this checklist. Materials should be labeled and recorded so that it is intelligible to a technically-qualified third party. 


\section{APPENDIX B}

\section{MONK VALIDATION}

\section{Validation Procedure}

The validation of the method used in the analysis consists of testing the ability of the MONK6A code (UKEAE, 1988) and neutron cross-sections in calculation of known critical configurations from various benchmark experiments with plutonium $(\mathrm{Pu})$ as the fissile material. Such analyses determine a calculational bias (the deviation of calculated $k_{\text {eff }}$ from unity) and the uncertainties culminating from the experimental and calculational errors.

The safety criteria for future calculations on undetermined systems requires that the biasadjusted $k_{\text {eff }}$ does not exceed 0.95 at the $95 \%$ confidence interval. This is expressed by the following equation;

$$
k_{\text {eff }}=k_{\text {calc }}-b i a s+\left(u_{b}^{2}+U_{c}^{2}\right)^{\frac{1}{2}} \leq 0.95
$$

where: $\quad \mathrm{k}_{\text {calc }}=\mathrm{k}$ value given by the calculation of the system

bias $=$ mean difference $\left(\mathrm{k}_{\text {calc }}-1.0\right)$ for benchmark criticals

$\mathrm{U}_{\mathrm{b}}=95 \%$ confidence level uncertainty in bias determination

$\mathrm{U}_{\mathrm{c}}=95 \%$ confidence level uncertainty in new calculation.

Thus, the bias-adjusted $\mathbf{k}_{\mathrm{eff}}$ includes the statistical uncertainties.

\section{Generic Validation of Plutonium Systems}

A report by Maklin and Miller (1992) presents the results of calculations to determine a generic bias for plutonium configurations, as encountered in the Plutonium Finishing Plant. Seventy benchmark experiments were calculated, ranging from simple metal spheres to highly diluted ( $9 \mathrm{~g}$ plutonium per liter) plutonium nitrate solution spheres, and compacts of $\mathrm{PuO}_{2}$ blended with polystyrene. A mean $k_{\text {eff }}$ value of 1.0047 was determined over the full experimental range, with an average standard deviation of 0.0097 .

The direct calculational bias is thus +0.0047 (average $\mathrm{k}_{\mathrm{eff}}$ greater than unity). Accounting for the uncertainties using tolerance limit analysis, the report then concludes that 
At least $95 \%$ of all critical experiments of this type computed by the MONK6A code will produce calculated $\mathrm{k}_{\mathrm{eff}}$ values greater than 0.9857 with $95 \%$ confidence.

For a standard deviation ( $\sigma$ ) of 0.01 or less for the convergence of a future calculation $\left(U_{c}\right)$, the 0.9857 value is lowered to 0.9855 . Rounded conservatively, a value of +0.015 can be used for [ -bias $\left.+\left(\mathrm{U}_{b}^{2}-U_{c}^{2}\right)^{1 / 2}\right]$. On this basis, it is determined that the true $\mathrm{k}_{\text {eff }}$ of an analyzed configuration with plutonium will not exceed 0.95 with a $95 \%$ confidence level if the calculated value $\left(\mathrm{k}_{\text {cale }}, 0 \leq 0.01\right)$ is limited to a maximum of 0.935 .

The $95 \%$ confidence level on $99.9 \%$ of the data is 0.9699 . So a subcritical margin of $5 \%$ is $3.5 \%$ larger than the uncertainties between the $95.0 \%$ and the $99.9 \%$ coverage of the benchmark data.

\section{Validation of MONK6B}

The validation of MONK6B code on the SUN microcomputer was documented in Miller (1994). The essence of the validation was cross-correlation of calculational results obtained with this code version and computer with results for identical model input done on a CRAY machine with MONK6A. Also, the equivalence of MONK6A and MONK6B was well documented by the vendor in the verification package shipped with the software. 
HNF-SD-SQA-CSA-522 Rev. 0

APPENDIX C

MONK INPUT FILES 
All MONK6B input and output files are stored in CFS in the directory /w80395/ in the file CSER96025.tar.Z, which is stored in tarred, then compressed format. The input names can be derived from the case names called out in the document, but with a ".inp" extension. Similarly, the output files are derived from the same case names, but with a ".prt" extension. The input files cskip.inp (worst case normal conditions), cint4.inp (worst case contingency condition), and owagon.inp (worst case condition with doors open) are included in complete form. [NOTE: The input file comments may or may not be consistent with the input file contents. For example, the Pu density of $5.0 \mathrm{~g} / \mathrm{cc}$ mentioned in the comments is not correct.] 


\section{MONK6B input file eskip.inp}

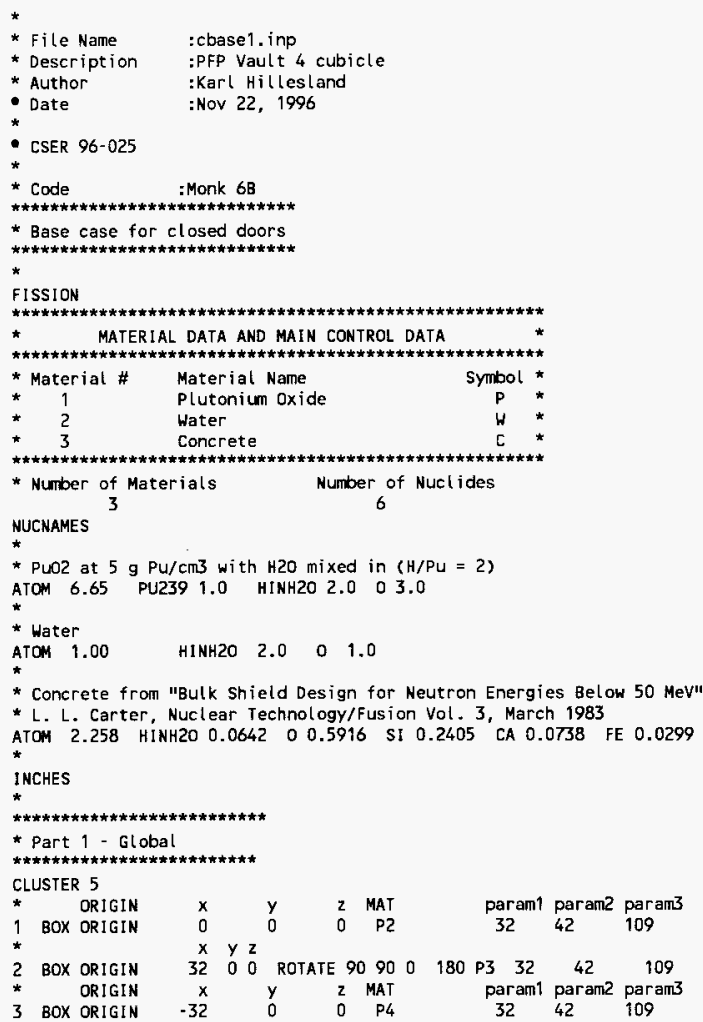

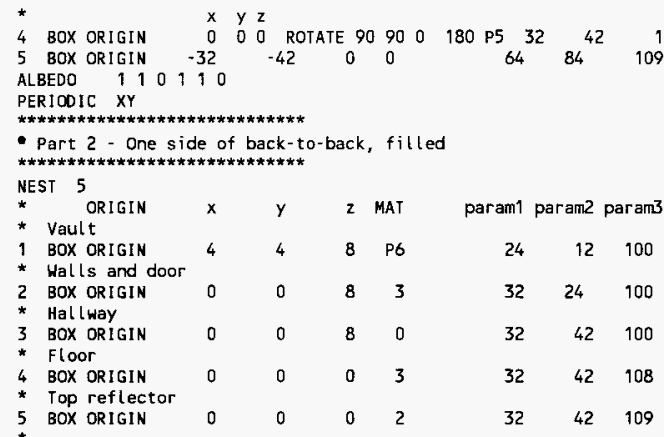

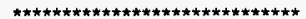

* Part 3 - One side of back-to-back, empty NEST 5

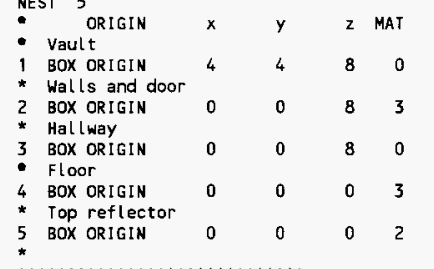

param1 param2 param3

$\begin{array}{rrr}24 & 12 & 100 \\ 32 & 24 & 100 \\ 32 & 42 & 100 \\ 32 & 42 & 108 \\ 32 & 42 & 109\end{array}$

* Part 4 - One side of back-to-back, empty

NEST 5

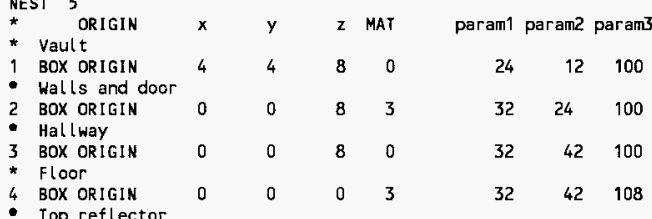
109

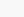


HNF-SD-SQA-CSA-522 Rev. 0

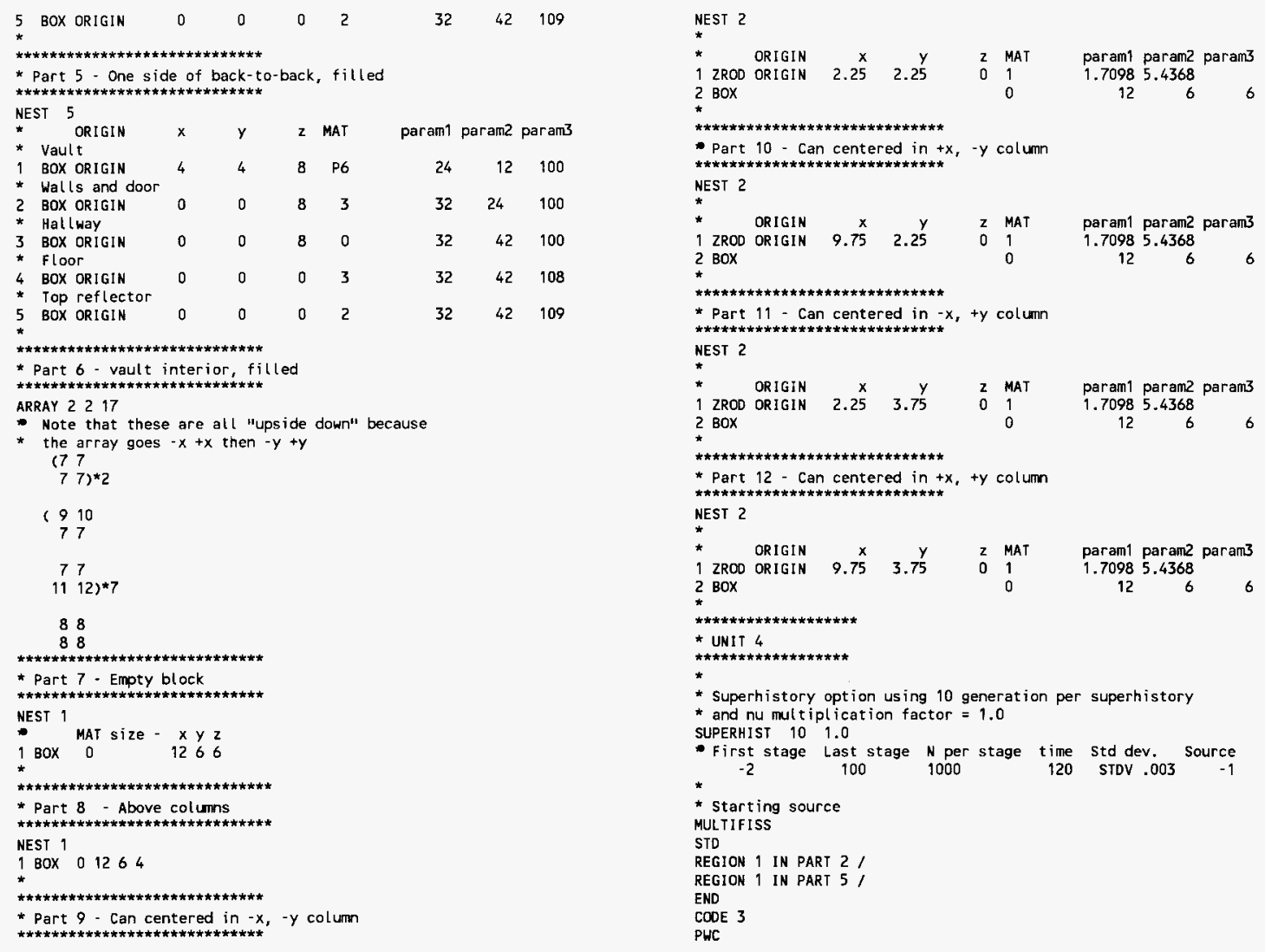




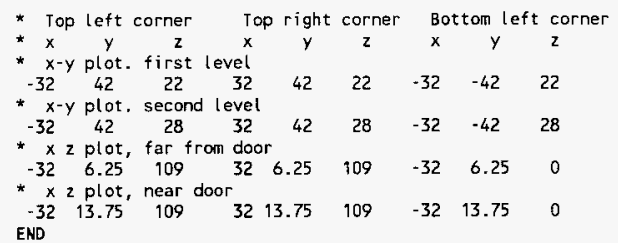

\section{MONK6B input file cint4.inp}

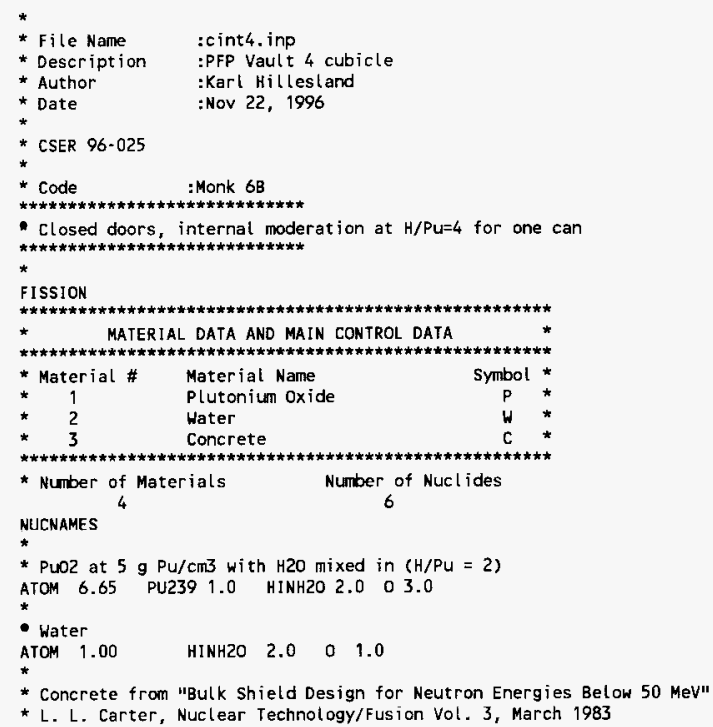

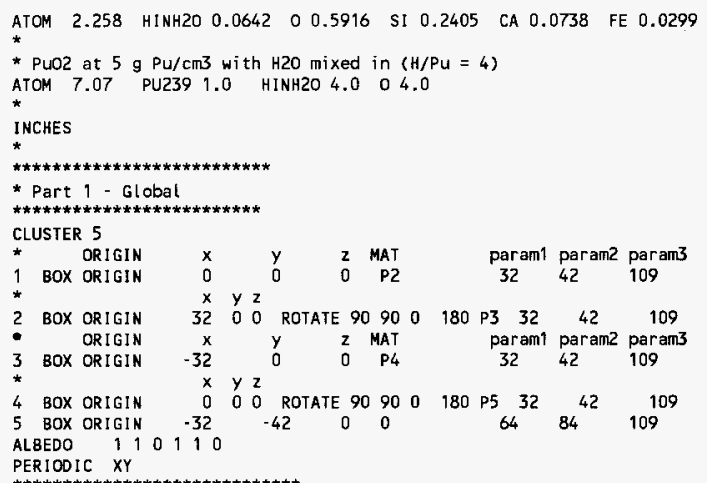

- Part 2 - One side of back-to-back, filled NEST 5

\begin{tabular}{|c|c|c|c|c|c|c|c|}
\hline $\begin{array}{l}\text { ORIGIN } \\
\text { Vault }\end{array}$ & $x$ & $y$ & $z$ & MAT & param1 & param2 & param? \\
\hline $\begin{array}{l}\text { BOX ORIGIN } \\
\text { Halls and door }\end{array}$ & 4 & 4 & 8 & P6 & 24 & 12 & 100 \\
\hline $\begin{array}{l}\text { BOX ORIGIN } \\
\text { Hal Lway }\end{array}$ & 0 & 0 & 8 & 3 & 32 & 24 & 100 \\
\hline $\begin{array}{l}\text { BOX ORIGIN } \\
\text { Floor }\end{array}$ & 0 & 0 & 8 & 0 & 32 & 42 & 10 \\
\hline $\begin{array}{l}\text { BOX ORIGIN } \\
\text { TOP reflector }\end{array}$ & 0 & 0 & 0 & 3 & 32 & 42 & 108 \\
\hline BOX ORIGIN & 0 & 0 & 0 & 2 & 32 & 42 & 109 \\
\hline
\end{tabular}

\section{*****************************}

* Part 3 - One side of back-to-back, empty NEST 5

\begin{tabular}{|c|c|c|c|c|c|c|c|}
\hline $\begin{array}{l}\text { ORIGIN } \\
\text { Vault }\end{array}$ & $x$ & $y$ & $z$ & MAT & param1 & ram2 & param3 \\
\hline $\begin{array}{l}\text { 80X ORIGIN } \\
\text { Halls and door }\end{array}$ & 4 & 4 & 8 & 0 & 24 & 12 & 100 \\
\hline $\begin{array}{l}\text { BOX ORIGIN } \\
\text { Hal Iway }\end{array}$ & 0 & 0 & 8 & 3 & 32 & 24 & 10 \\
\hline $\begin{array}{l}\text { BOX ORIGIN } \\
\text { FloOr }\end{array}$ & 0 & 0 & 8 & 0 & 32 & 42 & 10 \\
\hline BOX ORIGIN & 0 & 0 & 0 & 3 & 32 & 42 & 108 \\
\hline
\end{tabular}


HNF-SD-SQA-CSA-522 Rev. 0

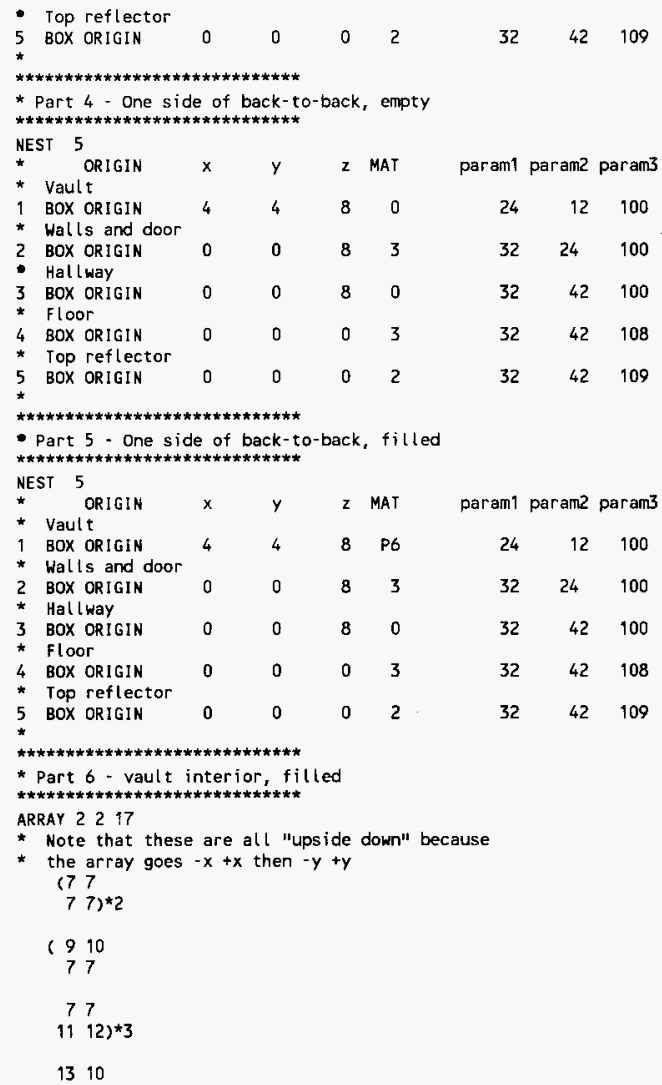

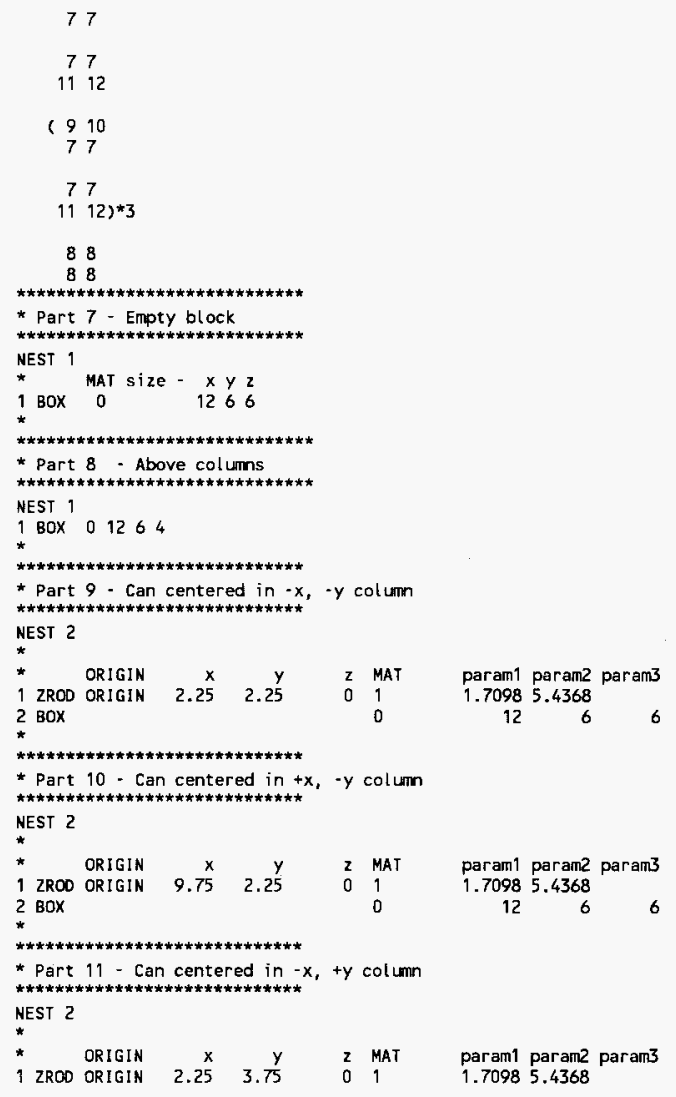




\section{MONK6B input file owagon.inp}

* Part 12 - Can centered in $+x$, ty column

NEST 2

$\begin{array}{lrrrrl}* & \text { ORIGIN } & x & y & z & \text { MAT } \\ 12 \text { 2ROD ORIGIN } & 9.75 & 3.75 & 0 & 1 \\ 2 & \text { BOX } & & & & 0\end{array}$

param1 param2 param3 2 BOX

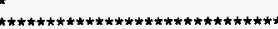

* Part 13 - Overbatched can centered in $-x,-y$ column

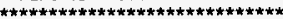
NEST 2

$$
\begin{array}{lrrrrrr}
* & & & & & & \\
* & \text { ORIGIN } & x & y & z & \text { MAT } & \text { param1 param2 param3 } \\
1 \text { ZROD ORIGIN } & 2.25 & 2.25 & 0 & 4 & 1.70985 .4368
\end{array}
$$$$
2 \text { BOX }
$$$$
0
$$$$
12 \quad 6
$$$$
\text { * }
$$

\section{$*$}

\section{* UNIT 4}

$$
\text { * }
$$

* Superhistory option using 10 generation per superhistory

* and nu multiplication factor $=1.0$

SUPERHIST $10 \quad 1.0$

$\begin{array}{cccccr}\text { * First stage Last stage } & \text { N per stage time } & \text { Std dev. } & \text { Source } \\ -2 & 100 & 1000 & 120 & \text { STDV .003 } & -1\end{array}$

* Starting source

MULTIFISS

STD

REGION 1 IN PART $2 /$

REGION 1 IN PART 5

REGION 1 IN PART 13 ,

END

CODE 3

PWC

* Top left corner Top right corner Botton left corner

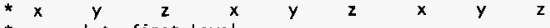

$\begin{array}{lllllllll}* & x-y & \text { plot. first level } & & & & & \\ -32 & 42 & 22 & 32 & 42 & 22 & -32 & -42 & 22\end{array}$

$\begin{array}{lllllll}-32 & x-y \text { plot. second level } & 42 & 22 & & & \\ -32 & 42 & 28 & -32 & -42 & 28\end{array}$

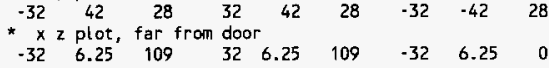

- $x$ z plot, near door

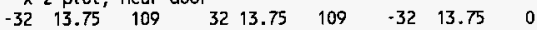

END

*

* File Name :owagon. inp

* :PFP Vault 4 cubicle

* Author :Karl Hillesland

* Date

:Nov 22, 1996

* CSER $96-025$

* Code

:Monk 6B

* Can level with center can in back column, no person, doors open

FISSION

* MATERIAL DATA aND MAIN CONTROL DATA

"Material

- Material \# Material Name

* 1 Plutonium Oxide

$\begin{array}{lll}* & 2 & \text { Water } \\ * & 3 & \text { Concrete }\end{array}$

Symbol *

* Number of Materials Number of Nuclides$$
3
$$

NUCNAMES

* Puor at $5 \mathrm{~g} \mathrm{Pu} / \mathrm{cm} 3$ with $\mathrm{H} 20$ mixed in $(\mathrm{H} / \mathrm{Pu}=2$ )

ATOM 6.65 PU239 1.0 HINH2O $2.0 \quad 03.0$

* Water

ATOM $1.00 \quad$ HINH2O $2.0 \quad 0 \quad 1.0$

" Concrete from "Bulk Shield Design for Neutron Energies Below $50 \mathrm{MeV}$ * L. L. Carter, Nuclear Technology/fusion Vol. 3, March 1983 ATOM 2.258 HINH2O 0.064200 .5916 SI $0.2405 \cdot$ CA 0.0738 FE 0.0299

INCHES

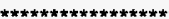

* Part 1 - Global

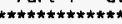

NEST 2

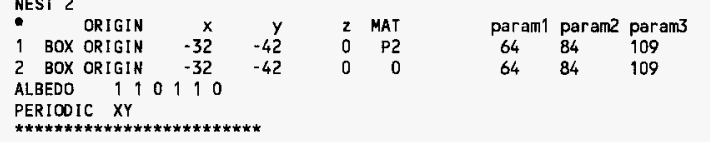


HNF-SD-SQA-CSA-522 Rev. 0

* Part 2 - Array of cubicles

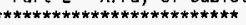

ARRAY 221

6534

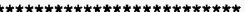

* Part 3 - +y side, empty cubicle, door closed NEST 5

\begin{tabular}{|c|c|c|c|c|c|c|c|}
\hline 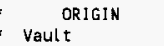 & $x$ & $y$ & 2 & MAT & param1 & param2 & 2 param3 \\
\hline $\begin{array}{l}\text { BOX ORIGIN } \\
\text { Walls and door }\end{array}$ & 4 & 4 & 8 & 0 & 24 & 12 & 100 \\
\hline $\begin{array}{l}\text { BOX ORIGIN } \\
\text { Hal I way }\end{array}$ & 0 & 0 & 8 & 3 & 32 & 24 & 100 \\
\hline $\begin{array}{l}\text { BOX ORIGIN } \\
\text { Floor }\end{array}$ & 0 & 0 & 8 & 0 & 32 & 42 & 1 \\
\hline $\begin{array}{l}\text { BOX ORIGIN } \\
\text { TOP reflector }\end{array}$ & 0 & 0 & 0 & 3 & 32 & 42 & $\eta$ \\
\hline BOX ORIGIN & 0 & 0 & 0 & 2 & 32 & 42 & $?$ \\
\hline
\end{tabular}

\section{BOX ORIGIN 0}

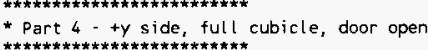
CLUSTER 8

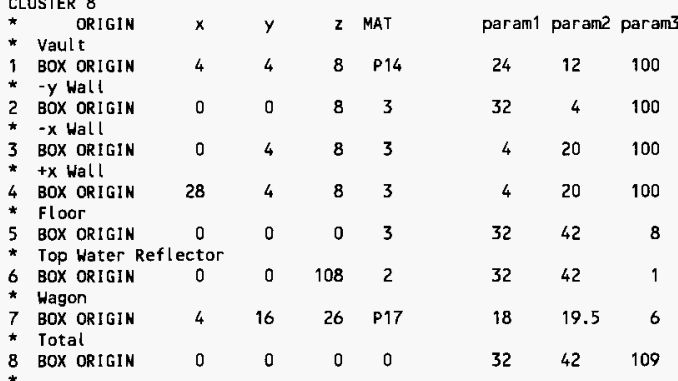

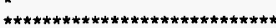

* Part 5 - -y side empty cubicle, doors closed

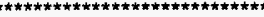

NEST 5

* ORIGIN $x$ y $z$ ROTATE $x$ y $z$ theta MAT

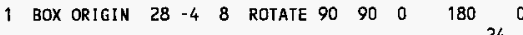

$24 \quad 12 \quad 100$

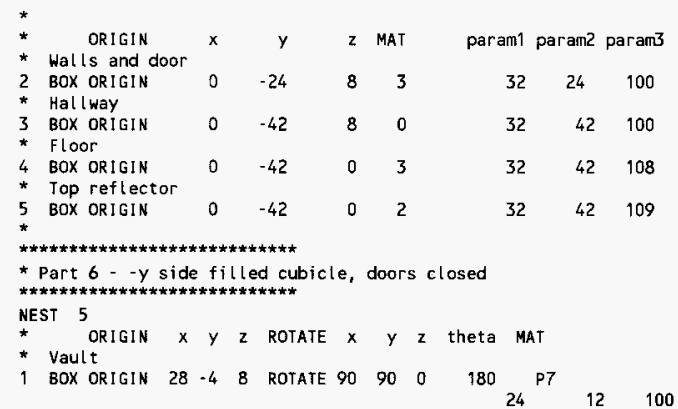

$$
\star
$$


HNF-SD-SQA-CSA-522 Rev. 0

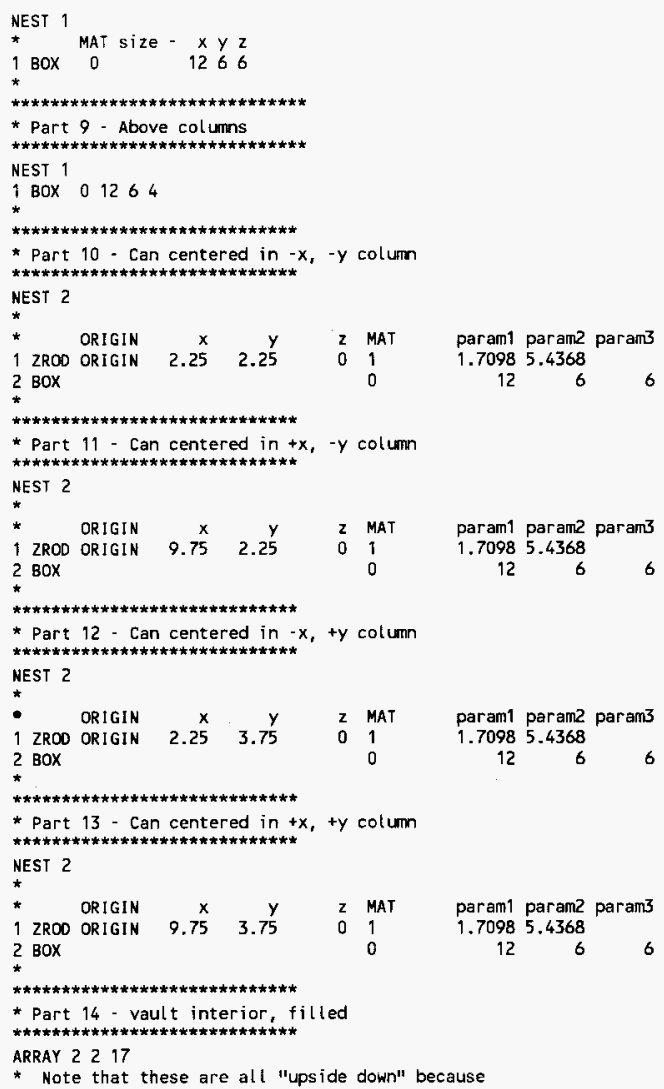

* Note that these are all "upside down" because

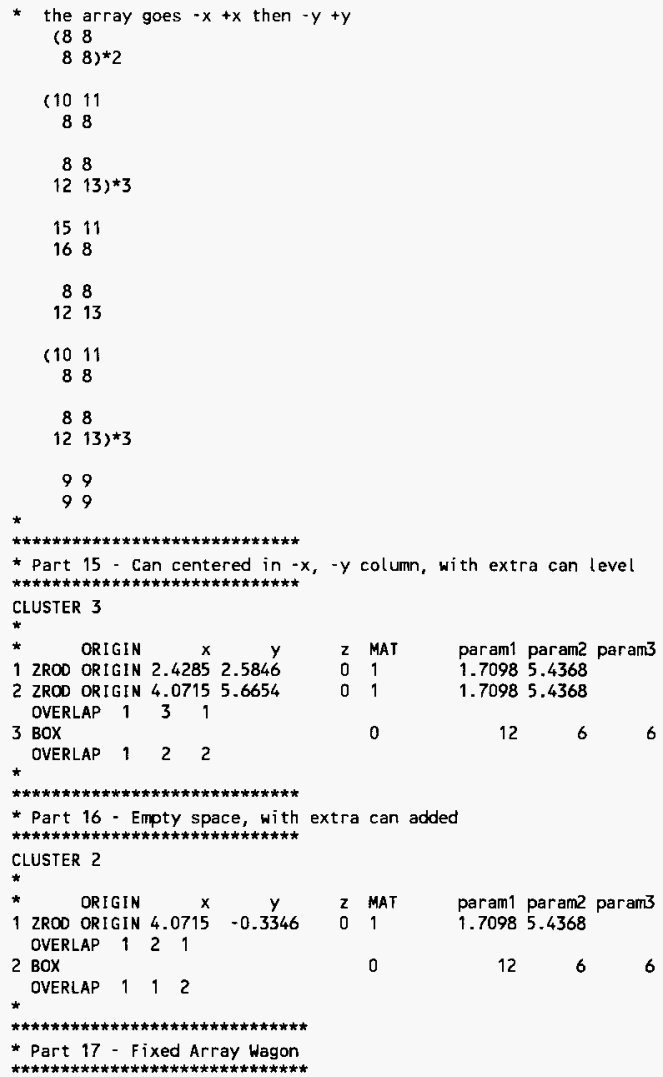




\section{HNF-SD-SQA-CSA-522 Rev. 0}

ARRAY 231

$(18)^{\star} 6$

* Part 18 - A can in the wagon

* Part 18 - A can in the wagon

NEST 2

* ORIGIN

1 ZROD ORIGIN

$\begin{array}{lr}x & y \\ 4 & 4.5\end{array}$

2 MAT

param1 param2 param3

2 BOX

0

1.70985 .4368

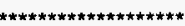

- UNIT 4

$\star \star \star * \star * \star \star \star \star \star * * * * * * * * * * * *$

$\star$

* Superhistory option using 10 generation per superhistory

* and nu multiplication factor $=1.0$

SUPERHIST $10 \quad 1.0$

* First stage Last stage N per stage time Std dev. Source

*

* Starting source

MULTIFISS

STD

REGION 1 IN PART 4

REGION 1 IN PART $6 /$

REGION 1 IN PART $15 /$

REGION 2 IN PART 15

REGION 1 IN PART 16

REGION 7 IN PART $4 /$

END

COOE

PWC

* Top left corner Top right corner Bottom left corner

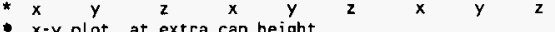

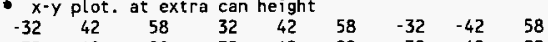

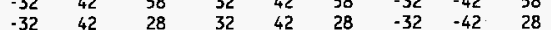

END 
DISTRIBUTION SHEET

\begin{tabular}{|c|c|c|c|c|c|}
\hline \multirow{2}{*}{$\begin{array}{l}\text { To } \\
\text { Distribution }\end{array}$} & \multirow{2}{*}{\multicolumn{2}{|c|}{$\begin{array}{l}\text { From } \\
\text { Criticality and Shielding }\end{array}$}} & \multicolumn{3}{|c|}{ Page 1 of 44} \\
\hline & & & \multicolumn{3}{|c|}{ Date $12 / 13 / 96$} \\
\hline \multirow{2}{*}{\multicolumn{3}{|c|}{$\begin{array}{l}\text { Project Title/Work Order } \\
\text { CSER 96-025: PFP Storage of } 9.25 \text { inch Ta11, } 4.4 \mathrm{~kg} \text { Pu Cans } \\
\text { on Existing Vault } 4 \text { Pedestals }\end{array}$}} & \multicolumn{3}{|c|}{ EDT No. 620285} \\
\hline & & & \multicolumn{3}{|c|}{ ECN No. N/A } \\
\hline \multicolumn{2}{|l|}{ Name } & $\begin{array}{l}\text { Text } \\
\text { With All } \\
\text { Attach. }\end{array}$ & $\begin{array}{l}\text { Text } \\
\text { Only }\end{array}$ & $\begin{array}{l}\text { Attach.I } \\
\text { Appendix } \\
\text { Only }\end{array}$ & $\begin{array}{l}\text { EDT/ECN } \\
\text { Only }\end{array}$ \\
\hline $\begin{array}{l}\text { E.P. Bonadie } \\
\text { K.D. Dobbin } \\
\text { D.G. Erickson } \\
\text { S.R. Gedeon } \\
\text { M.W. Gibson } \\
\text { J. Greenborg } \\
\text { K.E. Hillesland } \\
\text { S.F. Kessler } \\
\text { C.M. Kronval1 } \\
\text { J.S. Lan } \\
\text { W.S. Lewis } \\
\text { E.M. Miller } \\
\text { L.T. Nirider } \\
\text { S.E. Nunn } \\
\text { L.L. Pedersen (3) } \\
\text { A.L. Ramble } \\
\text { R.F. Richards } \\
\text { S.P. Roblyer } \\
\text { R.H. Ruben } \\
\text { K.N. Schwinkendorf } \\
\text { W.D. Wittekind } \\
\text { W.T. Watson }\end{array}$ & 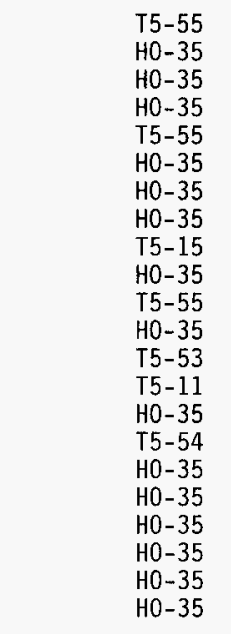 & $\begin{array}{l}x \\
x \\
x \\
x \\
x \\
x \\
x \\
x \\
x \\
x \\
x \\
x \\
x \\
x \\
x \\
x \\
x \\
x \\
x \\
x \\
x \\
x \\
x \\
x\end{array}$ & & & \\
\hline Central Files (Original +2) & $A 3-88$ & $x$ & & & \\
\hline
\end{tabular}

